Е.В. Краснощеков

\title{
BOЗHYKHOBEHYE
}

И PA3BYTYE

KATETOPYY

IOCECEYBHOCTM 


\section{Е.В. Краснощеков}

\section{ВОЗНИКНОВЕНИЕ И РАЗВИТИЕ КАТЕГОРИИ ПОСЕССИВНОСТИ}

Монография

Чебоксары 2019 
УДК 81

ББК 81.2

К78

\section{Рецензенты}

д-р филол. наук, доцент, заведующий кафедрой немецкого и французского языков факультета иностранных языков

Таганрогского института им. А.П. Чехова (филиал) ФГБОУ ВО «Ростовский государственный экономический университет (РИНХ)»

\section{А.М. Червоный}

канд. филол. наук, доцент кафедры лингвистического образования ФГАОУ ВО «Южный федеральный университет»

О.Г. Мельник

\section{Краснощеков Е.В.}

К78 Возникновение и развитие категории посессивности : монография / Е.В. Краснощеков. - Чебоксары: ИД «Среда», 2019. - 84 с.

\section{ISBN 978-5-6043214-4-7}

В монографии рассматривается возникновение и развитие категории посессивности в языках. Несмотря на определённое количество исследований в лингвистике, посвященных изучению категории посессивности в отдельных языках, систематическое исследование этой языковой категории в языках разных систем с последующим их сопоставлением и проведением сравнительного анализа в диахронно-типологическом аспекте представлено не было. Сравнительный анализ развития категории притяжательности с точки зрения контенсивной типологии даётся впервые, где представлен путь становления категории притяжательности в языке в целом, а также подчёркнута важная роль архаичных языков (на примере енисейских) для диахронических исследований.

Данное исследование вносит вклад в развитие общего языкознания, теории языка, типологии языков и может быть использовано при подготовке курсов по теории языка, лингвистической типологии на филологических факультетах, а также при написании работ по проблемам эволюции категорий языка.

DOI $10.31483 / \mathrm{a}-88$

(C) Е.В. Краснощеков

ISBN 978-5-6043214-4-7

(С) ИД «Среда», 2019 


\section{ОГЛАВЛЕНИЕ}

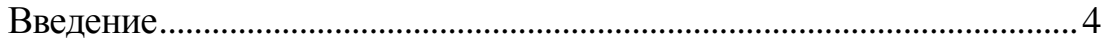

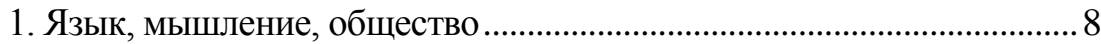

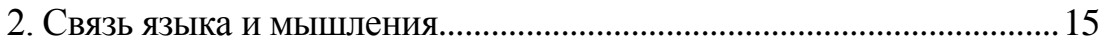

3. Посессивные отношения и их средства выражения на фоне

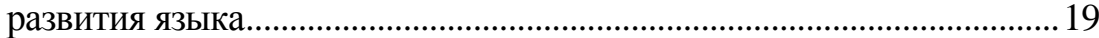

4. Притяжательные отношения и категория версии ................................38

5. Притяжательый «строй» как один из этапов развития языка в рамках эргативного строя.....................................................................46

6. Трансформация элементов категории притяжательности при переходе от эргативной структуры языка к номинативной ..................50

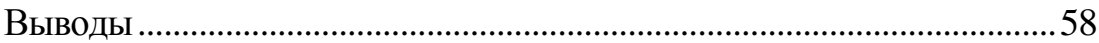

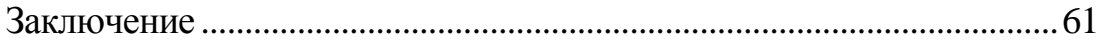

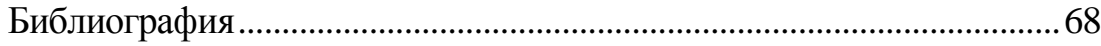

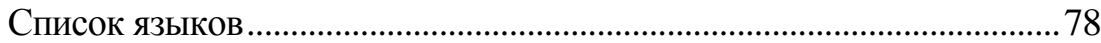




\section{ВВЕДЕНИЕ}

Начало XXI столетия ознаменовалась в развитии языкознания возрастанием интереса к проблемам диахронической лингвистики, что было мотивировано общим развитием лингвистической мысли последних десятилетий. Наука о языке стремится к построению такой лингвистической теории, которая обладала бы большей объяснительной силой по сравнению с чисто таксономическими построениями синхронной грамматики. Возрастание интереса к диахронической лингвистике обусловливает в известной мере возврат к обсуждению проблем, возникших в классическом индоевропейском сравнительно-историческом языкознании, и к освещению их с применением новых методов языкового описания, разработанных различными направлениями синхронной лингвистики и языковой типологии.

Этот последний аспект языкового анализа приобретает особое значение в современной лингвистике, поскольку он позволяет выявить универсальные языковые категории, характеризующие глубинные структуры языка, и определить степени различия между многообразными историческими языковыми системами.

Упомянутые исследования представляют очень ценный материал о категории посессивности (КП) в соответствующих языках, который мы старались использовать в своей работе. Эти труды важны для синхронного изучения КП в отдельных языках или в группах языков, однако, по ним невозможно сложить представление о КП в языке в целом.

В этой связи представляется актуальной проблема диахронической типологии КП в языке.

Такой подход, требующий строгого соблюдения принципа системности, наиболее зримо раскрывает язык в действии, в его конкретной реализации, что позволяет выявить богатые функционально-семантические возможности категории посессивности в языке.

В предлагаемой работе мы опираемся на данные енисейских языков (ЕЯ), а также других языков народов Сибири, находящихся на грани исчезновения. Именно в них сохранились реликтовые остатки различных периодов в развитии языка.

Материал ЕЯ мы сравним с развитием и становлением КП в европейских языках, а также в языках других систем. 
Кетский язык (КЯ) является последним представителем енисейской семьи языков и резко отличается от окружающих его алтайских, финно-угорских, самодийских и др. языков. С типологической точки зрения КЯ также явно не может быть отнесён к тому или иному морфологическому типу. Многие лингвисты отмечают, что грамматическая структура КЯ типологически чрезвычайно необычна [Werner, 1997: 3; Georg, 2000: 128; Вайда Э., 2000:21-41]. Характерными чертами языка являются: агглютинация, совмещенная с внутренней флексией; явно выраженное деление на классы у существительных; остатки активного строя при современном номинативно-аккузативном характере языка; уникальное использование субъектно-объектных маркеров в качестве компонента для деривации глагольных основ [Vajda, 2003]. КЯ обнаруживает определенные типологические параллели с отдаленными языками, такими как атабасские, эяк и тлингит в Северной Америке, бурушаски в Южной Азии, баскский язык в юго-западной Европе.

В ЕЯ категория притяжательности привлекает особое внимание. Показатели притяжательности встречаются в этих языках повсюду: ими оформляются глаголы, они встречаются в именах. В выражении притяжательности участвуют также местоимения и послелоги, существует притяжательное спряжение и притяжательное склонение, сближающие их с языками, в окружении которых они находятся [Краснощеков, 2008а: 88-94].

Грамматические формы и особенности их функционирования в значительной степени мотивированы социокультурным и историческим опытом носителей языка. В исследовании планируется проведение анализа сущностных особенностей такой мотивированности, что также определяет научную актуальность настоящей работы. Актуально само обращение к проблемам морфологических категорий, которые необходимо проанализировать на новых основаниях - в лингвокультурологической и антропоцентрической парадигмах.

Антропоцентрический принцип в современном языкознании традиционно распространяется на область лексики; давние традиции имеет антропоцентрический подход к анализу художественного текста, такого его элемента, как антропоцентрическая метафора. И гораздо реже антропоцентризм, связанный с рассмотрением языка в диаде «язык и человек», распространяется на материал грамматических категорий. Антропоцентрический подход, как «научная мегапарадигма», по отношению к которой остальные языковедческие парадигмы выступают в качестве более частных, 
позволяет объяснить многие факты (на первый взгляд - парадоксальные) в функционировании грамматических форм.

В работе использованы такие общенаучные методы исследования, как индуктивно-дедуктивный метод, применение которого предопределяет специфика диахронического исследования, метод системного анализа и синтеза; лингвистические методы дефиниционного, лексико-семантического, компонентного и концептуального анализа. Также использовались сравнительно-исторический, сопоставительный и контенсивно-типологический методы при диахроническом подходе, служащие выявлению сходств и различий средств выражения притяжательности в различных языках. В результате сопоставления удалось выявить совпадающие, сходные и несовпадающие явления в исследуемых языках, проанализировать причины возникновения различий.

По Ф. де Соссюру, предметом диахронической лингвистики являются отношения, связывающие элементы в порядке исторической последовательности, не воспринимаемые одним и тем же коллективным сознанием, - элементы, заменяющиеся один другим, но не образующие системы. Н.С. Трубецкой, Р.О. Якобсон и др. вслед за Бодуэном де Куртенэ считают, что диахроническое изучение не исключает понятие системы. Именно их взгляды разделяются автором предлагаемой работы.

Сравнительно-типологическое изучение языков дает возможность выявить структурные особенности различных языков: на его основании построена морфологическая классификация языков. При помощи сопоставительного метода изучаются степень и характер влияния одного языка на другой в результате исторических и территориальных контактов. Например, якутский (тюркские языки), в котором под влиянием окружающих языков был утерян родительный падеж; караимский (то же), где личные местоимения стали полностью совпадать с русскими притяжательными местоимениями.

Язык отражает каждое изменение, происходящее в обществе. Каждый конкретный язык обладает уникальными свойствами, присущими языку в целом. Язык развивается в тесном взаимодействии с мышлением.

Мышление людей развивается на базе пространственных понятий: «близко» - сфера 'Я'; в пределах видимости - сфера 'ТЫ' и «далеко» - сфера 'ОН'. Эти сферы обслуживали три гласных дейксиса: $i, u$, a (см. Г. Хирт 1925; К. Бругман 1933; Л. Грей, М. Бреаль 1939; К. Редея 1969 и др.). При классном строе языка эти 
дейксисы сопровождались согласными элементами в препозиции или постпозиции, уточняя класс денотата. Средства выражения притяжательнсти восходят к общему для них протоэлементу дейктической частице с диффузным значением, в том числе значение личных и указательных местоимений. Грамматикализация бывших дейктических частиц начинается в эпоху развитого активного строя в языке.

Развитие отношений посессивности связано с появлением в обществе зачатков собственности. Ориентация в пространстве лежит в основе категории посессивности. Обладатель и обладаемое мыслимы только в пространстве. Близко расположенное - моё; более далекое не моё.

До того как в языке появилась система падежей, притяжательные отношения выражались простым соположением имен.

Падежная система представлена при активном строе двумя падежами: активным и инактивным. Активный падеж личных местоимений положил начало притяжательным местоимениям.

Bce остальные средства выражения категории притяжательности являются производными от личных и притяжательных местоименй.

Для языков активного строя характерна категория версии, выражаемая дейктическими и классными элементами, например, в кетском языке это $b a$ - (центростемительное) $b o$ - (центробежное). Так, в абхазском языке версионный показатель 3- выражает в переходных глаголах принадлежность прямого объекта косвенному.

Показатели версии, вошедшие в состав глаголной словоформы, трансформировались в показатели категории притяжательности.

Если принять, что язык имел при позднеактивном строе различные виды структур, а именно: абсолютные аффективные, эргативные и посессивные, то можно считать, что в языке имелся посессивный строй (И.И. Мещанинов, Г.А. Климов, И.А. Мельчук, Г.К. Вернер, Г.Т. Поленова и др.).

Посессивная конструкция - это модель посессивного предложения эргативной типологии.

При номинативно-аккузативном строе языка вырабатывается унифицированная категория притяжательности (органическая + неорганическая), как, например в абхазо-адыгских, тюркских, уральских и др. языках. 


\section{1. ЯЗЫК, МЫШЛЕНИЕ, ОБЩЕСТВО}

Язык, его статус, место и роль в человеческом обществе постоянно являлся предметом спора многих ученых-лингвистов. Эти споры не утихают и до сих пор. Существует множество различных и даже противоречивых точек зрения по поводу его развития. С тех пор как появилась лингвистика - наука о языке, ученые не оставляют попыток определить понятие языка и обосновать универсальные законы его развития.

Я. Гримм писал по поводу развития языка, что: «Из всех человеческих изобретений, которые люди тщательно охраняли и по традиции передавали друг другу, которые они создали в содружестве с заложенной в них природой, язык, как кажется, является величайшим, благороднейшим и неотьемлемейшим достоянием» [Гримм Я., 1956: 64]. Р. Раск видел, что «... мир постоянно изменяется, возникает из незначительного, достигает наивысшего, затем снова возвращается назад, как говорят, в вечном круговороте. Однако я не думаю, что такое развитие следует называть круговоротом, так как ничто никогда не возвращается назад, а идет все дальше и дальше вперед в бесконечность ... Точно также и языки. Они возникают из простых звуков, развиваются и усложняются, а затем снова распадаются на простые звуки, но эти звуки никогда не бывают такими же, что и раньше... языки никогда не получат того же строя, что и раньше. Я думаю, что правильнее следовало бы сказать, что все в мире течет и изменяется в постоянном движении по спирали, а не в круговороте, так как в этом случае все когда-нибудь вернулось бы назад к исходному состоянию» (см. Кузьменко, 1984: 50).

Лингвистика, в общем и целом, как известно, восходит к идеям В. фон Гумбольдта, одним из первых однозначно признавшим и системно исследовавшим особый статус и уникальную природу языка. Он писал по этому поводу, что любой язык в отдельности уже является предметом, который заслуживает самого пристального осмысления. Язык - это не просто, как принято говорить, отпечаток идей народа, так как множество его знаков не позволяет обнаружить никаких существующих отдельно от него идей. Гумбольдт называет язык объединенной духовной энергией народа, которая чудесным образом запечатлелась в определенных звуках. Через взаимосвязь этих звуков она становится понятной всем говорящим и возбуждает в них примерно одинаковую энергию. Человек 
больше того, что можно выразить в словах; но ему приходится заключать в слова свой неуловимый дух, - чтобы скрепить его чемто, и использовать слова как опору для достижения того, что выходит за их рамки. «Разные языки - это отнюдь не различные обозначения одной и той же вещи, а различные видения ее; и если вещь aiajag - является предметом внешнего мира, каждый (говорящий) по-своему ее создает, находя в ней ровно столько своего, сколько нужно для того, чтобы охватить и принять в себя чужую мысль. Языки - это иероглифы, в которые человек заключает мир и свое воображение; при этом мир и воображение, постоянно создающее картину за картиной по законам подобия, остаются в целом неизменными, языки сами собой развиваются, усложняются, расширяются» [Гумбольдт, 1985: 348-349].

Идеалистический «историзм» (И. Кант, И.Г. Гердер) и позитивистский «компаративизм» (О. Конт, Г. Спенсер) послужили основой, на которой возникло сравнительно-историческое языкознание и уже в середине 19 века его стали рассматривать как образец для ряда других наук, основанных на идеях и принципах историзма и компаративизма. Язык рассматривался теперь как структура, контактирующая с психологическими и социологическими началами его носителей. Двумя разновидностями данного течения являлись натуралистические воззрения А. Шлейхера о национальных (этнических) языках как ответвлениях единого генеалогического древа языков и «теория волн» И. Шмидта. Цель обеих теорий - попытаться распространить единый закон языкового развития на различный языковой материал, разница между ними в том, что А. Шлейхер основным стержнем развития видит время, И. Шмидт - пространство. А. Шлейхер, к примеру, отмечал: «Языки - эти, образованные из звуковой материи природные организмы, притом самые высшие из всех, проявляют свои свойства природного организма не только в том, что они классифицируются на роды, виды, подвиды и т.д., но и в том, что их рост происходит по определенным законам» [Шлейхер, 1960: 95].

Г. Пауль, один из основателей Лейпцигской школы младограмматизма, подчеркивал: «Равномерный характер протекания всех языковых процессов у разных индивидов составляет важнейшую основу точного научного познания этих процессов - и далее ... Подлинным объектом языкового исследования является совокупность 
проявлений речевой деятельности всех относящихся к данной языковой общности индивидов в их взаимодействии.» [Пауль, 1960: $42,46]$.

Ф. де Соссюр утверждал, что язык - знаковая система (форма форм), которая существует в связи с наличием внешних, и внутренних факторов, что, естественно, обусловливает разграничение языка и речи, синхронии и диахронии, формы и содержания: «... Понятие языка (langue) не совпадает с понятием речевой деятельности вообще (langage); язык - только определенная часть, правда - важнейшая, речевой деятельности. Он, с одной стороны, - социальный продукт речевой способности, с другой стороны, - совокупность необходимых условий, усвоенных общественным коллективом для осуществления этой способности у отдельных лиц. Взятая в целом, речевая деятельность многоформенна и разносистемна. Язык, наоборот, есть замкнутое целое, и дает базу для классификации. Отводя ему первое место среди всех и всяких явлений речевой деятельности, мы, тем самым, вносим естественный порядок в такую область, которая иначе разграничена быть не может» [Соссюр, 2006: 34-35].

Г. Шухардт (школа «слова и вещи») видел в языке не только средство общения: « ... подлинная сущность языка заключается в его коммуникативной функции, то есть в передаче окружающим не только своей мысли, но также чувств и желаний, независимо от того, выражают ли последние то, о чем говорящий думает в момент речи» [Шухардт, 2003: 79].

Любое языковое выражение по своей сути является «индивидуальным, языковым творчеством. Сколько индивидуумов, столько стилей» [Фосслер, 2007: 33].

Достижения науки, представленные критиками младограмматизма, дали возможность создать новые течения в языкознании: структуральное, психологическое и социологическое. Специальным объектом исследования их был язык, который представлялся началом и следствием внеязыковых образований - психики и социума. Например, создатели психологического течения сравнивали язык с орудиями труда, поскольку «... он тоже принадлежит к жизненно необходимым инструментам, представляя собой органон, подобный вещественным инструментам, то есть материальным средствам, не являющимся частями тела. Как и орудия труда, язык есть специально сконструированный посредник. Только на этого 
языкового посредника реагируют не материальные предметы, а живые существа, с которыми мы общаемся» [Бюлер, 2000: 1-2].

Один из создателей нового социологического течения П. Лафарг, утверждал: «Если язык развивается, беспрерывно видоизменяясь, то происходит это потому, что он является самым непосредственным и характерным продуктом человеческого общества ... Язык отражает каждое изменение, происходящее в человеческом существе и в среде, где оно развивается» [Лафарг, 1936: 54].

Инициатор использования социологического метода в языкознании, А. Мейе, писал: «Язык существует лишь постольку, поскольку есть общество, а человеческие общества не могли бы существовать без языка» [Мейе, 2002: 52].

Таким образом, ответить на вопрос о сущности языка - означает показать соотношение языка с действительностью (бытием), социумом (обществом) и сознанием, мышлением (познанием).

Методологическим фундаментом интерпретации соотношения языка и общества в мировой науке стали теории О. Конта, Г. Спенсера и Г.В.Ф. Гегеля, Л. Фейербаха, К. Маркса, получившие свое развитие на [Яковлев, 2008: 97] Западе (К. Пайк, А. Гримшо, У. Лабов) и в СССР (позднее - России) соответственно; основными достижениями западной социолингвистики принято считать доказательство имманентности существования языка и общества, советской (российской) - обоснование их взаимодополнения.

В 20-м веке западная социолингвистическая мысль строилась на научной платформе структурализма. В Пражской (В. Матезиус, Р.О. Якобсон), Французской (А. Мейе, Ш. Балли) и Американской (Л. Блумфилд, Н. Хомский) школах, позволяющих интерпретировать язык как системно функционирующее, социально определенное и определяющее социум, генеративное целое соответственно; советская (российская) наука о соотношении языка и общества (Б.А. Ларин, Л.П. Якубинский, В.М. Жирмунский, Е.Д. Поливанов; А.Д. Швейцер, Ю.Д. Дешериев, Л.Б. Никольский, Е.А. Земская, Л.П. Крысин, Э.Г. Туманян) фундировалась на диалектическом материализме и описывала язык как комплексное материально-идеальное явление, проявляющее себя в процессах порождения (восприятия) речи и ее социализации.

«В 20-м веке ученые также пришли к выводу о включенности «доязыкового» (психического, психолингвистического), соб- 
ственно языкового (текстового) и социального («адресноориентированного») в единую сущность языка; более того - признали его (язык) нестатическим, функционирующим, генеративным целым, то есть оказались на пороге признания языка процессом (как следствие, - структурой) и экзистенциальной средой (затем - средством общения). Опыт философского, лингвофилософского, лингвистического и социолингвистического анализа, позволяет говорить о языке как процессе и экзистенциальной среде» [Яковлев, 2008: 98]. «Каждый конкретный язык обладает универсальными свойствами. Любой язык мира выступает как средство общения людей. И то, что язык есть средство общения, коммуникации, как раз и является основным его свойством. Осуществление коммуникативной функции требует от языка, с одной стороны, устойчивости, неизменяемости, с другой стороны, условия коммуникации, постоянно развивающееся мышление требуют от языка непрекращающегося развития, изменения и пополнения его элементов, усложнения и совершенствования функций. Таким образом, между состоянием языка в данную эпоху и потребностью общества к всё более адекватному выражению осложняющихся форм коммуникации существует постоянное противоречие. Именно оно является основным стимулом развития языка. Не всякое изменение в языке приводит к его развитию, а лишь то, которое влечёт за собой расширение и осложнение общественных функций языка» [Карташова, 2011: 17].

«Действительно, языки не могут не меняться, прежде всего, по той простой причине, что в основе актов коммуникации, средством практического осуществления которых и является язык, лежит отражение человеком окружающей его действительности. « ... язык в каждый момент своего существования представляет собой и деятельность, и исторический продукт этой деятельности. В объектах такого рода следует принимать во внимание два разных кинематических процесса - процесс генезиса объекта и процесс его функционирования» [Щедровицкий, 1963: 7-8]. Понятие исторического развития языка неполно без воссоздания закономерностей обоих этих процессов, ибо любое изменение начинается в речевой деятельности. Изменчивость языка - и предпосылка, и результат речевой деятельности, и условие и следствие нормального функционирования языка. Язык изменяется, - подчеркивает Э. Косериу, «чтобь продолжать функционировать как таковой»») [Косериу, 1963 : 156]. 
А. Мейе указывал, «Отмечая зависимость языка от различных причин, что лингвистические изменения обусловливаются, по крайней мере, тремя группами причин, или факторов: 1) структурой данного языка, т. е. здесь его устройством; 2) психологическими, физическими, пространственными, социальными и прочими условиями его существования; 3) теми частными влияниями других языков, которые в данное время и данном месте испытывает изучаемый язык» [Мейе, 2004].

К факторам первой группы он относил «факторы внутренние, интралингвистические, и их специфика определяется в равной мере и той звуковой субстанцией, в которую воплощён данный язык, и той сеткой связей, которая существует между его элементами (структурой языка) и, наконец, объединением элементов и связей в особое целостное единство (систему)» [Карташова, 2011:18].

Все факторы, которые упоминал А. Мейе во втором пункте своей классификации, обычно относятся к факторам экстралингвистическим. Факторы, причисяемые им к третьей группе, - это своеобразные полулингвистические причины; то, какой именно язык влияет на язык изучаемый, и каково соотносительное социальное положение двух языков является фактором экстралингвистическим, социально-экономическим или даже политическим. То, какие именно формы принимает языковое контактирование, зависит непосредственно от самих соприкасающихся языков, и в этом смысле воздействие одной лингвистической системы на другую можно рассматривать как внутрилингвистический процесс.

Мартине А. пишет по этому поводу: «Регулярное воздействие факторов: когнитивных, психологических, социальных на функционирование языка порождает ряд внешних и внутренних законов языкового развития»») [Мартине, 1965: 16-17].

Внешние законы обнаруживают устойчивые связи с различными сторонами человеческой деятельности, с историей общества. Они охватывают норму и содержательную сторону языка. Внешние законы развития разделяются на общие и частные. Общие устанавливают взаимосвязь, характерную для всех языков: связь общей истории языка с историей общества, связь форм существования языка с историческими общностями людей, зависимость развития языка от территориально-географических условий его функционирования (виды контактирования языков: субстрат, суперстрат, 
адстрат). Частные законы характерны для конкретных языков и ряда родственных.

Изменения в языке могут быть и результатом действия внутренних факторов. Они порождаются самим языковым механизмом независимо от внешних условий функционирования языка. Главная особенность, отличающая внутренние причины языковых изменений от внешних в том, что внутренние изменения не имеют никаких временных ограничений. Внутренние причины определяют, как правило, тенденции развития данного языка, количественные и качественные изменения в нём.

Основные внутренние причины по Б.А. Серебренникову - это:

1) приспособление языкового механизма к физиологическим особенностям человеческого организма;

2) необходимость улучшения языкового механизма;

3) необходимость сохранения языка в состоянии коммуникативной пригодности [Серебренников, 1968: 60-61].

Эти причины порождают ряд тенденций, отмеченных А. Мартине:

1) стремление к облегчению произношения (редукция гласных, ассимиляция);

2) тенденция к выражению одинаковых или близких значений одной формой (выравнивание по аналогии);

3) тенденция к устранению форм и категорий, утративших свою исконную функцию (например, утрата категории рода в английском языке);

4) стремление к экономии языковых средств, к ограничению сложности языковых сообщений, к формированию языков с простой морфологической структурой [по Мейе, 2004 ].

Для цели нашего исследования важно сделать следующие выводы:

- Язык отражает каждое изменение, происходящее в обществе.

- Существование каждого национального языка предопределено в его языковой природе единым устройством языка вообще.

- В основе изменения языка лежит отражение человеком окружающей его действительности.

- Язык в каждый момент своего существования представляет собой и деятельность, и исторический продукт этой деятельности. 


\section{2. СВЯЗЬ ЯЗЫКА И МЫШЛЕНИЯ}

С языком, как известно, тесно связано мышление. По этой причине проблема соответствия особенностей языка уровню развития мышления давно интересовала исследователей.

Ф.Ф. Фортунатов писал по этому поводу: «Язык, как мы знаем, существует главным образом в процессе мышления и в нашей речи как в выражении мысли, а, кроме того, наша речь заключает в себе также и выражение чувствований. Язык представляет поэтому, совокупность знаков главным образом для мысли и для выражений мысли в речи, а, кроме того, в языке существуют и знаки для выражения чувствования» [Фортунатов, 1956:111].

К.Д. Ушинский отмечал в своих трудах: «Принимая язык за органическое создание народной мысли и чувства, в котором выражаются результаты духовной жизни народа, мы, конечно, поймем, почему в языке каждого народа выражается особенный характер, почему язык является лучшей характеристикой народа» [Ушинский, 1988: 112].

Человеческий язык - это необычное явление, представляющее собой сплав мышления и речи и созданное природой, гением человеческого общества в процессе совместной трудовой деятельности. Человечество пока не знает другого изобретения, которое можно было бы сравнить с языком.

Любой человеческий язык обслуживает общество, народ, социальные группы, а также различные идеологические направления. Существуют разные формы мышления и соответствующие им разные типы языков.

Способность мыслить заложена в самой природе человека. Поэтому мышление - такая же реальность, как само существование человека. Без мышления нет человека.

Природная способность человека говорить - сущностное свойство его бытия, первичное данное, само же говорение - это проявление природной способности человека. Общечеловеческое мышление, связанное с говорением, можно было бы назвать мышлением универсальными понятиями.

Языковому мышлению данного конкретного этноса, идиоэтническому мышлению соответствует конкретная лингвистика. Чем больше удалены друг от друга разные идиоэтнические мышления, тем больше удалены и соотносительные языковые структуры. 
Структурную близость эргативного баскского языка к кавказским можно объяснить лишь общностью идиоэтнического мышления носителей этих языков, удаленность же структур номинативного русского языка и эргативных кавказских языков - удаленностью идиоэтнического мышления. Не могут существовать структурные различия языков без соответствующих различий в мышлении их носителей. Единому языковому мышлению может соответствовать только единый язык.

Об эргативном строе языка С.Д. Кацнельсон писал: «Вышколенному в нормах традиционной грамматики уму эргативный строй представляется чудовищным извращением всех грамматических канонов» [Кацнельсон, 2004: 68]. Могут ли существовать «чудовищные отличия грамматических канонов» без соответствующих отличий в мышлениях, языковые отличия сами по себе, отличия в мышлениях - сами по себе? В этом отношении определенный интерес представляют взгляды П.К. Услара и К.Д. Ушинского. П.К. Услар подчеркивал: «Индивидуальность народа обусловливается особенностью его языка и особенностью его склада понятий, его цивилизации» [Услар, 1870: 2]. Он также высказывал такую мысль: «Скольким бы языкам мы ни выучились, ни один не запечатлеется в целом духовном мире нашем так глубоко, как язык родной, - язык, которым непосредственно выражается своеобразный склад наших понятий. Это относится ко всем народам и ко всем языкам в мире» [Услар, 1870: 17].

Каждый народ индивидуален, его индивидуальность обусловливается особенностью языка и его понятий, так как язык непосредственно выражает своеобразный склад наших понятий - в этих мыслях П.К. Услара заложено четкое понимание основной сущности проблемы связи языка и мышления с духовным миром человека.

Мышление и язык так же первичны, как и их носитель - человек. Казуистически рассматривая их сущность как отражение реального мира, некоторые антигумбольдтовцы не хотят признать, что мышление и язык не только отражают в себе действительную жизнь, но сами являются частью этой же действительности, ее древнейшими проявлениями. Язык является не только хранилищем богатейшего опыта людей и орудием их общения между собой, но также орудием самовыражения человека. 
Язык и мышление развиваются в тесном взаимодействии. Развитие и обогащение одного из них влечет за собой развитие и обогащение другого. Поэтому познание сущности языка тесно связано с познанием мышления.

В зависимости от уклада жизни, окружающей среды, психологии, нравов и обычаев у каждого народа существуют свои понятия. Эти понятия и определяют объем значений, характерных для данного конкретного языкового мышления. Эти же понятия определяют и характер использования конкретных значений.

Однако, говоря словами В.З. Панфилова, «наличие типологических различий между языками не исключает существенной общности этих языков, позволяющей рассматривать конкретные языки как представителей одного рода - человеческого языка» [цит. по Гишев, 2012: 179-184]. Исходя из такого положения вещей, многие типологические различия, например, русского и адыгейского языков, могут быть представлены как результат различной реализации универсалий.

Критикуя гумбольдтовскую идею влияния языка на мышление, в качестве ее антитезы можно выдвинуть гумбольдтовское же положение, согласно которому «каждая мысль может быть выражена в любом языке».

И В.А. Звегинцев прав, когда пишет о том, что «различия составляют незначительную долю в сравнении с тем, что у людей нашего земного мира является общим. Именно поэтому в их языках фиксируется огромное количество общих понятий, хотя и разными языковыми способами / средствами» [Звегинцев, 1960].

За бесконечным поражающим многообразием языков мира скрываются общие для всех них свойства. При всем безграничном несходстве оказывается, что языки созданы как бы по единому образцу. Хотя формально описаны лишь некоторые сходные свойства языков, лингвисты во многих случаях осознают их наличие и пользуются ими для описания новых языков. При этом они используют языковые универсалии, которые по своей природе являются обобщенными высказываниями о тех свойствах и тенденциях, которые присущи любому языку и разделяются всеми говорящими на этом языке. 
Подведем итоги:

Язык - это органическое создание народной мысли и чувства, где выражаются результаты духовной жизни народа, его особенный характер, и служит его лучшей характеристикой.

Способность мыслить заложена в самой природе человека, мышление - такая же реальность, как само существование человека. Без мышления нет человека.

Мышление и язык так же первичны, как и их носитель - человек; мышление и язык не только отражают действительную жизнь, но сами являются частью ее.

Познание сущности языка тесно связано с познанием мышления народа.

Существующие между языками различия не исключают существенной общности языков, позволяющей рассматривать различные языки как представителей одного рода - человеческого языка.

В языках фиксируется огромное количество общих понятий, хотя и разными языковыми способами. Таким общим понятием являются синонимичные понятия принадлежности, притяжательности, посессивности.

К рассмотрению эволюции категории посессивности и составляющих ее элементов мы и перейдем в следующей части нашего исследования. 


\section{3. ПОСЕССИВНЫЕ ОТНОШЕНИЯ И ИХ СРЕДСТВА ВЫРАЖЕНИЯ НА ФОНЕ РАЗВИТИЯ ЯЗЫКА}

Эволюция - процесс медленный. В процессе эволюции как считал А.А. Потебня, первобытные люди использовали однословные предложения, которые могли обозначать самые различные явления, например; Птица. Большая. Летит. Высоко. Такие высказывания могли быть использованы и в определённых ситуациях. По этому поводу А.А. Потебня пишет следующее: «слово, предполагаемое лексическою частью (лек-) глагола летит, означало не действие, взятое отвлеченно, а еще неразложенное восприятие, безразличную совокупность предмета и действия, например, не полет, приписываемой птице, а летящую птицу без всякого разложения этого явления. Ближайшее значение части лек в глаголе летит есть примета или признак, коим восприятие, например, летящая птица, намечается мыслью для дальнейшей мысли. Такое же значение в той же мере предполагается и именем и есть столь же доименное, как доглагольное. Это лек (или его первообраз) само по себе, без дополнения со стороны местоименного корня могло составлять первобытное предложение» [Потебня, 2014: 83]. Подобное словопредложение могло обозначать: птицу, её величину, действие, которое она совершает, высоту её полёта и т.д. Это Лек могло использоваться и в отношении летящего предмета - камня, копья, стрелы, поскольку лексический запас в древнем языке был крайне ограничен. Именно поэтому первые слова в языке первобытных людей обладали полисемантичностью. Вначале она была настолько широкой и неупорядоченной, что её можно охарактеризовать как синкретическую или диффузную.

По Г.Т. Поленовой, человеческая речь на ранней стадии ее развития стремилась выразить любое отношение в терминах места и пространства. «Локальными уточнителями были гласные: $i / e-u$ - $a / o$, а согласные элементы $k, t, q, n, x, b, s$ отражали классность. Слова имели структуру $C V$ или $V C$ в метатезе» [см. Поленова 2002: 20-21; 2011: 40].

В древнейший период в протоенисейском языке существовали простейшие дейктические частицы $i / e-u-a / o$, выражавшие три типа 
указания: Ich-Deixis 'сфера говорящего', Du /Der-Deixis 'нейтральная сфера' и Jener-Deixis 'сфера тот', по Бругману [Brugmann, 1904: 9-12]. Например, «... звук ' $\boldsymbol{a}$ ' выражал также действие вообще, безотносительно ко времени, обычное вневременное, всеобщее презенс, ср.: кет. ul-a-ta 'идет дождь', bed-a-ta 'идет снег'» (см. Поленова, 2002).

При раннеактивном строе языка звук ' $\boldsymbol{a}$ ' был дейксисом женщины, что подтверждают примеры из кетского и коттского языков. Это положение отражают, по-видимому, и формы вокатива, см. таблицу № 1, ср. кетский звательный падеж: «ата 'мама!', obo! 'отец!'» (см. Поленова 2005).

Таблица 1

Кетские падежные показатели, различающие классы

\begin{tabular}{|c|c|c|c|c|}
\hline Падеж & $\begin{array}{c}\text { Ед. число, } \\
\text { мужск. класс }\end{array}$ & $\begin{array}{c}\text { Ед. число жен./ } \\
\text { вещной }\end{array}$ & $\begin{array}{l}\text { Мн. число } \\
\text { одушевл-й }\end{array}$ & $\begin{array}{c}\text { Мн. число } \\
\text { неодушевл-й }\end{array}$ \\
\hline Родительный & $-d a$ & $-d(i) /-t$ & $-n a$ & $-d(i) /-t$ \\
\hline Дательный & -daya & -diga & $-n a \eta a$ & -diga \\
\hline Бенефактив & $-d a t a$ & -dita & -nata & - dita \\
\hline Аблатив & -dayal' & -digal' & -nayal' & -digal' \\
\hline Адессив & -dayta & -dinta & -nayta & -dinta \\
\hline Вокатив & $-\breve{O}-$ & $-a$ (жс.)- & & \\
\hline
\end{tabular}

[Поленова : 29]

Поленова считает, что во времена матриархата [Морган, 1935], при классном строе, звук ' $\boldsymbol{a}$ ' был дейксисом человека и олицетворяемых явлений и животных - Genus Commune. Различия по полу еще не существовало. Класс вещей выражался нулем. «При матриархате основная оппозиция классов была "одушевленный / неодушевленный" (с учетом первобытной картины мира) и выражалась через $x a$, $a x / x o, o x, x u, u x, x i, i x$, структуры звуков $C V / V C$, где $x$ - любой согласный звук» (см. работу Поленовой Следы классного строя : 40).

Показатели классов $k, t, q, n, x, b, s$ выступали в глагольных формах как детерминативы. Они уточняли, к какому роду актантов относится действие или состояние. Дейктическими частицами пользовались для связи слов, присоединяя их в качестве энклитиклв.

В современном кетском языке некоторые из первичных дейктических частиц сохранились как предикативные показатели: «1-е лицо -di; 2-е лицо -gu; 3-е лицо муж. кл. -du, жен. кл. -da; безличный предикатив -s'i. Сравним: o:ydi 'я здоров', aqtagu 'ты добрый', 
$s^{\prime} e l ' d u$ 'он плохой', təylda 'она высокая', eigs 'i' 'идущий'» [Поленова, 2011: 201].

Роль дейктических частиц в становлении языка, как уже было отмечено, не раз подчеркивала Т.М. Николаева, что «... они могут вполне удачно вписываться в языковую систему. . . Они становятся союзами, они становятся артиклями (в широком смысле детерминативами), они становятся частицами» [Николаева, 2008: 107]; и далее «...и местоимения, и глагольные флексии восходят к общему для них протоэлементу, являющемуся, как правило, дейктическим показателем» [Николаева, 2002: 27].

О восхождении личных местоимений к первичным указательным частицам писал и А.А. Потебня: «Личные окончания, как знаки связи сказуемого с подлежащим, образовались из указательных слов, имевших вещественное значение. До этого не было ещё глагола-сказуемого... В этих пределах местоимение есть или существительное, или прилагательное... Первоначальное различие между словами качественными и указательными... является лишь второстепенным основанием деления этих категорий». [Потебня, 2006: 45-47]. Сравним с мнением К. Бюлера, отмечавшим, что от указательных частиц происходят как личные, так и указательные местоимения [Bühler, 1934: 107-108], а также с мнением разделившей эту точку зрения К.Е. Майтинской: «При этом указательные и личные местоимения могли развиться от разных или тождественных первичных указательных частиц» [Майтинская, 2009: 196].

Мы, в свою очередь, считаем, что первичные слова-предложения и были такими простейшими построениями звуков из согласных и гласных, причем именно гласный являлся дейктическим элементом. Они послужили средством различения рода, числа, падежа имени, лица глагола и др.

Дальнейшей ступенью в развитии языка можно, вслед за Г.К. Вернером, считать зарождение двусловных предложений, в которых функции слов уже в известной мере определены, начинается дифференциация. Сказуемое получает специальный показатель сказуемости, предвестника будущих предикативных показателей. Это первое разделение функций слов как составных компонентов предложения обусловило появление класса знаменательных и подкласса служебных слов, которые в дальнейшем каждый по-своему дробятся на другие классы слов. Этот древний способ формирования классов слов, т.е. путем перехода слова в другой класс, 
включая переход знаменательных слов в служебные, а служебных - в аффиксы (в «пустые» слова-морфемы), сохраняется в языках мира до сих пор.

Служебный класс, пополняясь за счет перехода в него знаменательных слов, в зависимости от развития грамматической системы языка, продолжает дробиться: «из первичных синкретичных словдейксисов или слов-классификаторов постепенно вычленяются различные разряды местоимений, частицы, позднее предлоги, послелоги и с развитием паратаксиса и гипотаксиса - союзы» [Вернер, 1986: 6].

Следуя теории Г.А. Климова, Г.Т. Поленова, основываясь на картине мира кетов и собственных реконструкциях праязыкового енисейского состояния, представила развитие кетской грамматики в соответствии с изменениями в общественных отношениях от матриархата к патриархату, и в языке от классного строя к номинативному через активный строй языка. Первичные дейктические частицы со структурой CV/VC она отнесла к классному строю, когда любой согласный выступал классификатором, а гласные непосредственно дейктическими элементами.

Формирование собственно грамматики автор отнесла к активному строю языка, когда классно-дейктические частицы стали указательными местоимениями (ср. кет. $k i$ 'этот'; $t u$ 'этот', 'тот'; qa 'тот'), показателями агенса (ba-, bo-, bu-, bi-), категории действия, процесса, сказуемостности (ср. кетские предикативные показатели: $d i$ 1-е л., $k u$ - 2-е л., $d u$ - 3-е л. м.р., $d a$ - 3-е л. ж.р.).

В типологическом плане интересно заключение Ю.С. Степанова о том, что «В древних индоевропейских языках повторяющимся элементом часто является какая-либо специальная дейктическая частица ... *1. -v-//-m.; *2. -t-; *3. -n- дейксисы трех лицучастников акта речи» [Степанов, 2017: 73-74].

Важно отметить, что в первичных дейктических частицах классифицирующим формантом-опорой был консонант, что не раз подчёркивалось в трудах учёных, обращавшихся к проблемам диахронической типологии, начиная с К. Бругмана (см., например, работы Николаевой Т.М., Поленовой Г.Т. и др.). Н.А. Баскаков относительно материальной общности алтайских языков отметил следующее: «Все форманты аффиксов лица и принадлежности имеют в своей основе чередующиеся по языкам и диалектам губные согласные $m \sim b \sim f \sim w$-рефлекс начального губного согласного в основе 
личного местоимения 1-го лица (ср.: кет. $a b$ - 'мой', родит. падеж местоимения 1-го лица; $b$ - притяжательная приставка 1-го лица ед. числа - Е.К.) [Баскаков, 1981: 58].

Реконструируемый древний период языка, по Т.М. Николаевой, имел «непарадигматическое состояние». Эволюцию первичных дейктических частиц для славянского ареала Т.М. Николаева представляет следующим образом:

- «На первом этапе консонантные опоры партикулы не различают глухих и звонких. Семантика их диффузна и в дальнейшем может различаться даже в пределах родственных языков.

- На втором этапе выделяются будущие 'изолированно функционирующие партикулы'. Происходит формирование кластеров. Партикулы приобретают более чёткое значение...

- На третьем этапе (точнее, последнем) происходит окончательная грамматикализация изолированных партикул, распределившихся по союзам, частицам, местоимениям, словоформ с партикулами-флексиями, партикульных кластеров разной таксономии». [Николаева, 2008: 200, 321].

В кетском языке согласные $-b-,-k-(-g-),-d-$, вошли в состав личных местоимений 1-го, 2-го и 3-го лица притяжательного падежа в качестве посессивных элементов. Как правильно отмечает Т.М.Николаева: « ... партикулы (частицы) любят «прилипать», в том числе и прилипать друг к другу. Тогда они становятся местоимениями, например $\kappa b+m o, \kappa b+m o+m o$; они становятся частицами, напри-

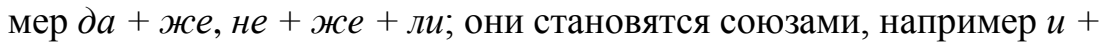
ли, $u+$ но, $a+$ по и т. д.» [Николаева, 2008: 108].

Категория посессивности (притяжательности) существует во всех языках и для ее выражения есть различные средства. Прежде всего, это специальные показатели, которые могут входить в состав, практически, любой части речи в зависимости от типа языков, а также окончания родительного падежа, личные и указательные местоимения.

Например, выражение посессивных отношений посредством лично-притяжательных суффиксов тюркских языках. Как считают Серебренников Б.А., Гаджиева Н.З., уже в праязыке должна была существовать система лично-притяжательных показателей, первоначально имевших, скорее, характер энклитик, но впоследствии 
явно превратившихся в аффиксы. Лично-притяжательными показателями служили формы единственного, множественного (возможно, даже и двойственного) числа личных местоимений (без местоименных суффиксов) или модифицированные варианты этих форм [Серебренников, Гаджиева, 1979 : 78].

Это наглядно подтверждают примеры из монгольского старописьменного языка, где выразители категории личного притяжания находятся еще на стадии выделения: они по своей форме не отличаются от родительного падежа соответствующих личных местоимений, но занимают фиксированное постпозитивное положение по отношению к имени, а изредка также пишутся несколько иначе, чем местоимения в род. падеже (см. табл. 1).

Таблица 1

\begin{tabular}{|c|c|c|c|c|c|c|}
\hline \multirow{2}{*}{\multicolumn{2}{|c|}{ Лицо / Число }} & \multirow{2}{*}{\multicolumn{3}{|c|}{$\begin{array}{c}\text { Личные местоимения } \\
\text { в форме род. падежа }\end{array}$}} & \multicolumn{2}{|c|}{ Личные частицы } \\
\hline & & & & & \multirow{2}{*}{$\begin{array}{c}\begin{array}{c}\text { совпадающие с } \\
\text { местоимениями }\end{array} \\
\text { minu } \\
\end{array}$} & \multirow{2}{*}{$\begin{array}{c}\begin{array}{c}\text { отличающиеся } \\
\text { от местоимений } \\
\text { mini } \\
\end{array}\end{array}$} \\
\hline 1-е л. & ед. & minu & 'меня', & 'мой' & & \\
\hline & MH. & manu & 'нас' & 'наш' & manu & mani \\
\hline \multirow[t]{2}{*}{ 2-е л. } & ед. & činu & 'тебя', & 'твой' & činu & čini \\
\hline & MH. & tanu & 'вас', & 'ваш' & $\operatorname{tanu}$ & tani \\
\hline \multirow[t]{2}{*}{ 3-е л. } & ед. & inu & 'него' & 'них' & inu & \multirow{2}{*}{ inu//anu//ni } \\
\hline & MH. & anu & 'его' & 'их' & anu & \\
\hline
\end{tabular}

Из табл. 1 нетрудно видеть, что частицы личного притяжания произошли от форм род. падежа соответствующих личных местоимений. Если в письменной и устной формах монгольского языка эти частицы довольно близки к местоименным формам, то в бурятском и калмыцком они в значительной мере деформировались.

Самостоятельный, независимый от местоимений характер личных частиц, в частности в бурятском языке, проявляется в том, что они могут употребляться наряду с формами род. падежа соответствующих местоимений, от которых эти частицы некогда произошли: минии нухэрни 'мой товарищ (мой)', танай турэһэн нютагт-

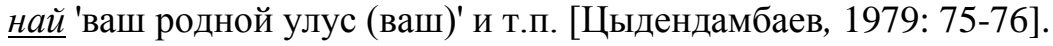

Сюда же следует отнести семантические аналоги притяжательного падежа - аналитические и изафетные конструкции, так называемый status constructus в арабском языке, где нет глаголов «бытия» и обладания, таких как: иметь, обладать (принадлежать, располагать чем-л., иметь в распоряжении) и др., поэтому выражение 
посессивности/ притяжательности, происходит иными способами (нежели в языках располагающих вышеуказанными глаголами). Прежде всего - это приименные способы и в 1-ю очередь конструкции с идафой ('ị̂āfah).

Конструкция с идафой может выражать обладание, принадлежность, совместное пребывание.

Эта конструкция представляет собой именную группу, где первое существительное выражено исходным падежом, а второе существительное или личное местоимение - род. падежом, т.е. два существительных в словосочетании находятся в отношении примыкания друг к другу, или же следуя друг за другом, образуют «идафную» цепочку.

Грамматические отношения в данном случае уточняются с помощью значка kasrah, который обычно ставится в конструкции под буквой: 'iḍ̂afah [Fischer, 1972: 7].

Частным случаем определительных словосочетаний являются изафетные конструкции в тюркских языках. Этот тип отношений между двумя именами пронизывает всю структуру тюркских языков, являясь как бы ключом к пониманию многих синтаксических категорий. Особенности этого типа синтаксических отношений кроются не только в его своеобразной природе, выходящей за рамки всех прочих атрибутивных отношений, но и в его нестандартном поведении в отдельных тюркских языках [Гаджиева, Cеребренников, 1986 : 50].

В традиционной грамматике обычно выделяют три типа изафета: 1-й тип изафета имеет только терминологическое значение, поскольку первый его член может быть настолько адъективизирован, что фактически данный тип изафета представляет собой чисто адъективизированные словосочетания. Именные словосочетания образуются с помощью примыкания и чаще всего оба компонента выступают в основном падеже. Например: азер. дэмир гапь - 'железная дверь', башк. көмөш akca - 'серебряные деньги' (дословно: 'серебро-деньги') и т.д.

Отличительным признаком 2-го типа изафета в тюркских языках является наличие притяжательного аффикса 3-го лица $y$ второго члена изафетной конструкции, ср. азер. гоз агачы -'ореховое дерево', хакас. інектің сӥдi - 'молоко коровье'.

3-й тип изафета соответствует полному притяжательному словосочетанию. Конструкция образуется по определенной схеме. 
Первый член представляет форму род. падежа, второй имеет притяжательный аффикс 3-го лица. Примеры: азер. овчунун хатирәләри - воспоминания охотника; хак. театр товынццылары 'сотрудники театра': баш. Ғафуризең, китабы - 'книга (принадлежавшая) Гафури'.

Средством выражения категории принадлежности могут быть также различные падежи.

Например в кетском языке, в атрибутивном употреблении основной (абсолютив) падеж выражает посессивное отношение подобно определяющему слову в немецких сложных существительных, например: среднекетск. $t \AA^{?} h i: t$ 'хвост окуня (вообще)'; ср. нем. Fischschwanz 'рыбий хвост'; кет. on 'ogden ti'? $n$ 'diya deestittan 'они её положили в семиушный котёл' (семь + уши + котёл + Dat.); s'ej 'ejit ko:ne 'поплывем до лиственничного острова' [Дульзон, 1968 : 74].

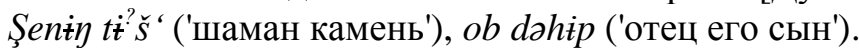

Лишительный падеж (каритив) указывает на предмет, без которого совершается действие, выражает отрицательную посессивность, например: dimman $k \varepsilon:^{?} t$ 'холостой человек' (букв. 'человек без жены, человек не имеющий жены': qim 'жена', -an - показатель лишительного падежа), ul'l'an $b a^{?} \eta$ 'местность без воды' (ul' 'вода') [Werner, 1997b: 116].

Таким образом, любое явление, признак, характеристика могут быть представлены в языке как утверждаемые, так и отрицаемые.

По смыслу всякое отрицание есть утверждение противоположного. Утверждая: «у меня есть эта книга», я одновременно отрицаю её отсутствие у меня. Диалектически понимаемое отрицание есть такое «нет», которое одновременно содержит в себе «да», т.е. отрицание и утверждение составляют единство.

В нашем случае можно сказать, что лишительный падеж (каритив) указывает на «отрицательную посессивность», ср.: tapas 'c собаками, имея собак' (совместный падеж), tappan 'без собак, не имея собак' (tap - 'собаки'); am 'мать', amman 'без матери', ul' 'вода', ul'l'en 'без воды', sen 'олени', sennan 'без оленей'; а когда слово оканчивается на гласный, между аффиксом и этим гласным вставляется звук

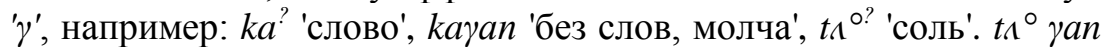
'без соли'.

Аффикс an встречается в вариантах: -ın, -in, -әn, -in, появляющихся в зависимости от характера соседнего гласного, наличия или 
отсутствия ударения. Приведем примеры употребления лишительного падежа, кет. sanosen 'oyon loktokkin 'охотники пошли без лыж'; s'uidan at to'kkadiYut 'без платка не бегай'; и т.п. (см. Дульзон, 1968:

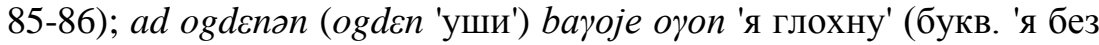
ушей становлюсь'); at qaүan (qa 'слово') diskerit 'я замолчу' (букв. 'я без слова лягу') [Максунова, 2009: 157]. Именно в этом смысле можно говорить, что лишительный падеж имеет отношение к отрицательной притяжательности.

К группе падежей, основанием для образования которых служит родительный падеж, относится исходный падеж (аблатив) (аффиксы: -dijal -ж.р. ед. ч. неод. предметы - мн. число, -dayal м.р. ед.ч., -nayal-мн. ч., одуш. предметы). Исходный падеж может обозначать:

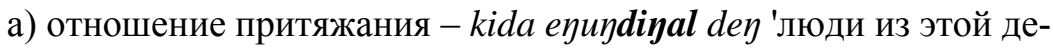

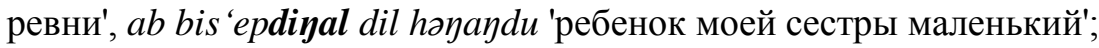

б) партитивные отношения - ba:m diya na?ndiyal lamt daqobintet 'старуха ей от хлеба кусок отрезала', $i$ :sdiyal bu dob de obijaq' 'она дала своему отцу рыбы', ani buynayal di:mdis ' 'кто из них пришел'?

Местно-личный падеж (адессив) также выражает посессивные отношения: budayt bən ob bən am 'у него ни отца, ни матери', abiyta duot u:s 'am 'у меня шило есть', homganayta se:n obilden 'у тунгусов были олени', sa:nnayta hai hu: usay 'у белок сердце есть' [Валл, 1985: 33].

Назначительный падеж (бенефактив) указывает, для кого или чего выполняется действие, и выражает предназначенность субъекта лицу или предмету, например: кет. bu qaldata ts'ul's'ivet 'он делает внуку нарты' (qal 'внук'); кет. kire ietn ad dibət dildat 'эту юколу я для ребенка делаю'; bu bindadata ak hastu 'он для себя дрова рубит' (по Дульзону, 1968: 86, 87).

В последнем случае можно отметить типологическое сходство с юкагирским языком, где значение формы предназначенности совпадают с кетским языком Ср.: юкаг. тит-л'уорилол итэт 'игрушки для вас сделаю'; ачиэги кэлуон-мод'угэ ничахадаим 'на месте, по которому отец его должен прийти, воткнула; тит хон эд'уон-мод'y нуктамэт? 'вы где питание (предназначенное для жизни) найдете?' [Крейнович, $1958: 66-67]$.

Иногда формы бенефактива заменяются формами местно-личного падежа (адессива), например: bu dakıtnayta an's'ivet (вместо dakıtnata) 'он думает о своих детях'; qi·p keyass'en'nayta as'к^?t t- 
tovin'gij (вместо keyass'en'nata) 'дед рассказывал сказку о птицах'. Функция адессива - обозначение лица с оттенком посессивности (в переводе с лат. adesse означает 'быть в наличии'); в большинстве случаев он обозначает лицо, у которого происходит действие. В словаре лингвистических терминов О.С. Ахмановой адессив представлен, как категориальная форма падежа, указывающая на местонахождение, принадлежность, орудие действия [Ахманова, 1966: 33]. Например: кет. bil'de $t \wedge^{2} t$ qimadiyta duyin' 'все их дети

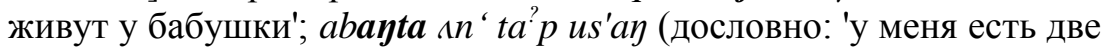
собаки'); qimdil' damdiyta das' $\varepsilon s^{\prime} t \varepsilon$ 'девушка сидит у своей матери'.

Таким образом, мы показали, что категория притяжательности пронизывает всю систему кетских падежей.

Но до того, как в языке появилась система падежей, притяжательные отношения выражались простым соположением имен. Ср.: вывод К.Е. Майтинской в статье «Неопределенный падеж и абсолютная форма в венгерском языке»: «...древнейшим способом выражения притяжательных связей было простое расположение одного имени перед другим и произношение их одним речевым тактом. Вероятно, не только у «обладателя», но и у «обладаемого» отсутствовал оформитель, указывающий на другой член словосочетания: отсутствовали как падежные (генитивные), так и лично-притяжательные окончания» [Майтинская, 1948: 72]. В кетском языке это легко подтверждается примерами типа: кет. $t \Lambda^{?} h u: t$ 'хвост окуня'; $っ$ ? $n$-əgden ti? ndiya deestittan 'они её положили в семиушный котёл' (семь + ушки + котёл); $s$ 'єnәך $t \dot{t}^{?} s^{\prime}$ ' 'шаманский камень' (букв. шаман + камень).

Об использовании модели «имя в номинативе + имя в номинативе» с притяжательным отношением между компонентами в прафинно-угорском, и в прауральском языке-основе свидетельствуют факты в языках-потомках, где и в настоящее время посессивные составляющие части словосочетаний выражают застывшие формы атрибутивных сочетаний в виде сложных слов и устойчивые сочетания, например, эрз. каткалевкс 'котенок', мокш. пеккедъ 'брюшина', венг. hegytetö 'вершина горы', napfény 'свет солнца', саам. penne tork 'собачья шкура', фин. aaltopituus 'длина волны', манс. katpatta 'ладонь', удм. йщлльыл 'сливки', Иван пи 'сын Ивана', мар. Йьвван вате 'жена Ивана', колхоз пасу 'колхозное поле', сельк. кыт канык 'берег реки' и т.д. (см. Краснощеков, 2013: 40-43). 
С развитием падежной системы притяжательный (родительный) падеж начал вытеснять старый способ выражения притяжательности, но, тем не менее, этот способ в качестве словосложения сохранился до наших дней. Многие языки и в настоящее время продолжают интенсивно обогащаться сложными словами, возникающими путем безаффиксального сложения слов. Например: эрз. узереобушка 'обух топора', чивалдо 'свет солнца', утомгенкш 'дверь амбара', алдюжа 'желток', лавтовбря 'плечо', ортатуло 'засов'; венг. fogsor 'ряд зубов', ujjhegy 'кончик пальца', inggallér 'воротник рубашки' и другие (см. Краснощеков, 2012: 140-145).

Падежная система в енисейских языках появилась на базе оппозиции двух падежей: основного и притяжательного. Первоначально падежная оппозиция возникла в сфере местоимений, из противопоставления форм основного и притяжательного падежей. В кетском языке в формах склонения личных местоимений 1-го лица единственного числа есть две основы - основа $\boldsymbol{a d}$ - (форма основного падежа) и основа $\boldsymbol{a b}$ - (форма притяжательного падежа). Их оппозиция восходит к состоянию, когда в праенисейском языке существовало два ряда личных местоимений - активный, когда обозначался активный субъект действия, и инактивный, когда обозначался субъект, пребывающий в определённом состоянии (см. Валл, Вернер, 1973: 28-30). На сегодняшний день, в падежной системе енисейских языков существует две группы падежей: 1-я группа на базе основного и 2-я на базе притяжательного (родительного) падежа.

В притяжательном падеже компонент окончания $(-b-,-k-,-d-)$ имеет лично-поссесивное значение: $a b$ - 'мой', $u k$ - 'твой', buda/budi - 'его/еe'.

Происхождение посессивной функции в языке связывается с локативной. Не случайно, что именно пространство выступает как модель схемы притяжания - отчуждения. Вместе с тем пространственная интерпретация выступает как наиболее естественная и в более общих случаях и при детализации отношений обладаемого и обладателя. В мифопоэтических системах обладатель и обладаемое мыслимы только в пространстве [ср.: Топоров, 1983: 100]. 


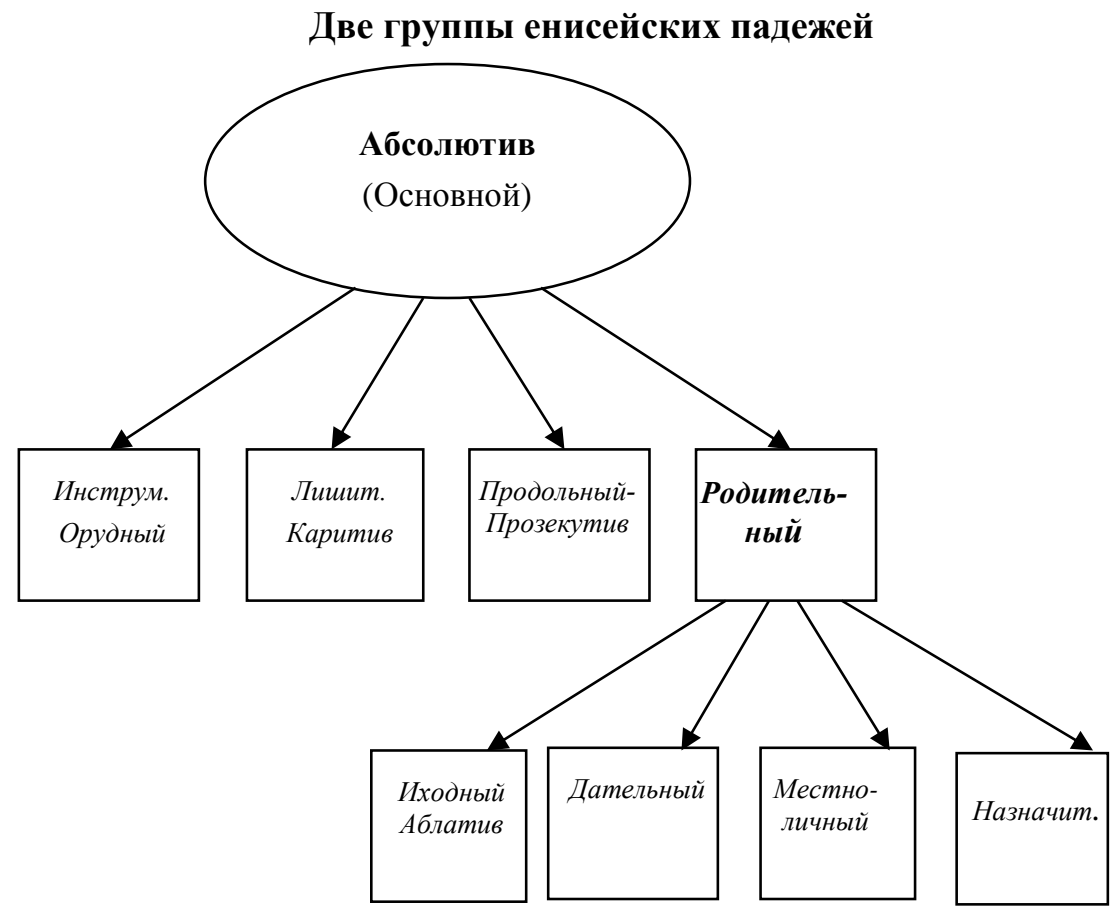

Выражение пространственных отношений посредством относительных имен (обозначений типа 'верх' - 'низ') может служить одним из наиболее наглядных примеров того, как локативные отношения могут переплетаться с посессивными. Например, в тюркских языках наиболее близко расположенное было переосмыслено как «мое», «мне принадлежащее», более далеко расположенное как «не мое» и т.д. Поэтому притяжательные аффиксы, здесь (в тюркских языках) развились из местоименных основ, выполняющих первоначальную роль пространственных индикаторов. Amblм 'моя лошадь' могло первоначально обозначать «лошадь, которая ближе всего ко мне находится». Постпозиция аффикса здесь такая же, как и у других указательных формантов, обозначающих место, ср. тур. евдеки 'находящийся в доме', алт. тайгадагы 'находящийся в тайге' и т. п. (см. Серебренников, Гаджиева, 1979: 99).

В хакасском языке: Пулар тӱрче хаңһада, алаң ас napыn, oдырчатханнар. - 'Они (эти), растерявшись, недолго сидели в телеге'. 
Сыдаспин пуларнаң, тіп, тӧреен чирінзер наныбысхан - 'Он сказал, что не выдержал с ними (этими) и возвратился в родные края' [Баскаков, 1975: 151].

В енисейских языках: kidu 'тот, этот относящийся / принадлежа-

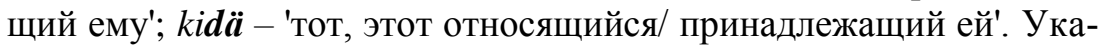
зательные местоимения $k i \cdot r, t u \cdot r, q a \cdot r$ 'этот', 'тот' также могут выражать значение притяжательности. Например: tur 'e bat kajnem ku:s`o:ks' 'этот взял палку'; keto, korö kunra qa u bat dasa:niit 'товарищ, та, о которой я тебе было говорил'; Xo? $n$ kau da biggulu ture ke:re tta 'ire sitabank 'Хонь, как посмотрела на эту женщину, так догадалась' (см. Валл, 1972: 33-34). К. Бругманн предполагал, что и в индоевропейских языках к указательным местоимениям восходят личные местоимения не только 3-го лица, но и 1-го и 2-го лица (см. Майтинская, 2009:197).

Генетические связи личных местоимений с указательными местоимениями прослеживаются, кроме енисейских, в финно-угорских и индоевропейских языках, в алтайских и семитских языках, во многих языках Австралии и Северной Америки [Кассирер, 2002: 149], в адыгских языках Кавказа [Кумахов, 1989 : 84, 94]. Так, Боас И. высказал мнение, что в языке индейцев тлингит самостоятельные личные местоимения происходят от указательных местоимений (см. Майтинская, 2009: 201). Например, в языке индейцев чероки (Сев. Америка) употребляется девять разных местоимений 3-го лица (в зависимости от того, стоит ли, сидит ли, ходит ли и т. д. лицо, о котором говорится). В североамериканском языке квакиутль имеется одно личное местоимение для 1-го лица, одно для 2-го лица, но семь личных местоимений для 3-го лица, которые различаются по указанию на степень удаленности, по видимости или невидимости лиц, а также по их присутствию или отсутствию (см. Майтинская, 2009). Венгерский языковед Д. Фокош высказал в свою очередь мысль о том, что указательные и личные местоимения происходят от первичных указательных частиц (см. Николаева, 2008: 207).

Наиболее логичным и естественным представляется путь развития трех личных местоимений от трех первичных дейктических частиц.

В енисейских языках отношение принадлежности, считаем, также возникало как результат переосмысления отношений пространственных. Притяжательные аффиксы в енисейских языках 
развились из местоименных основ, выполняющих первоначальную функцию пространственных индикаторов.

Примеры из кетского языка подтверждают связь отношений принадлежности с отношением пространственности: ad kom kora käral kainem 'я это от того человека взял'; kadä hiseiga o?ne asen 'в той тайге много зверей'.

В современном кетском языке и сейчас синонимичны притяжательные формы с суффиксом родительного падежа - дә и локативные конструкциии типа qui-day-ta bul'ay toqnam 'у лося (мест.личн. пад.) ноги тонкие' (см. Валл, 1985: 34).

В якутском языке в роли притяжательного местоимения может употребляться личное местоимение: мин amblм 'моя лошадь'. Отношение притяжательности в языке суахили выражается при помощи притяжательной частицы - $\boldsymbol{a}$. В результате слияния этой частицы с местоименными префиксами различных классов образуется много различных показателей притяжательности (см. Серебренников, 1988: 13).

Во многих языках существует притяжательное склонение. Суть притяжательного склонения заключается в том, что здесь принадлежность предмета или лица кому или чему-нибудь выражена в самих словах, обозначающих этот предмет (лицо), аффиксами личной принадлежности. К ним присоединяются в основном те же падежные аффиксы, что и в простом склонении, с незначительными в ряде случае фонетическими изменениями.

Их происхождение связывается с местоимениями, а именно с формами родительного падежа личных местоимений. Данный тип склонения присущ всем тюркским языкам.

Лично-притяжательное склонение существует и во всех монгольских языках, во всех языках тунгусо-маньчжурской группы, в палеоазиатских языках, в финно-угорской группе. По мнению О.А. Осиповой возможность индоевропейских существительных с основами на консонанты (склонение существительных $\boldsymbol{n}$ - основ) выражать определенность и посессивность можно квалифицировать как реликтовые посессивные образования. Этот тип склонения в и.-е. языках, т.е. склонения на консонантной основе можно рассматривать как посессивные склонения [Осипова, 2010: 77-78].

Тип притяжательного склонения можно наблюдать также в языках Кавказа. Притяжательные формы имен в абхазском языке об- 
разуются с помощью притяжательных префиксов, как и в енисейских языках: $\boldsymbol{c}$ - $a н$ 'моя мать', $\boldsymbol{y}(b l) л а$ 'твоя собака', л-аб 'ее отец', 'pboнbl 'их дом' и т. Во всех диалектах другой группы языков - адыгейских, имя также может соединяться с притяжательными и указательными префиксами.

Вместе с тем в этом типе склонения в языках есть и свои особенности. Например, в большей части тюркских языков существует стабильный морфологический показатель тюркского притяжательного склонения, так называемый «вставной» $\boldsymbol{n}$. В различных тюркских языках сфера действия «вставного» - $n$ - имеет ограничения в отношении лица категории принадлежности. Чаще всего это имена с аффиксами принадлежности 3-го лица.

Показателями притяжательности во многих языках оформляются не только имена, но и глаголы.

Посессивное (косвенно-объектное) спряжение отмечено в палеоазиатских языках, Рассматривая выражение притяжательности в глаголах различных языков, а также существующее в них притяжательное спряжение, мы видим, что в большинстве из них глаголы оформляются показателями притяжательности. Эти показатели выступают в качестве аффиксов личного спряжения, но представляют собой посессивные, энклитические формы личных местоимений. Позднее эти притяжательные аффиксы, продолжая постепенно изменяться, превратились в односложные притяжательные морфемы. Например, в тофаларском языке имена существительные могут выступать в качестве сказуемого. В этом случае существительные, как и другие именные части речи, оформляются специальными постпозитивными показателями сказуемости, указывающими на лицо. В хакасском языке местоимения 1-го и 2-го лица, утратив характер самостоятельного слова, сливаются с именем сказуемого на правах его оформителя, т.е. переходят в разряд аффиксов. Это служат подтверждением, что в прошлом языков был период, когда имена и глаголы оформлялись одинаковыми формантами притяжательности.

Среди языков чукотско-камчатской группы притяжательность охватывает систему глагола. В юкагирском, эскимосско-алеутских языках глаголы также оформляются показателями притяжательности.

В тунгусо-маньчжурских языках глаголы имеют две группы личных предикативных показателей. Показатели одной группы 
совпадают по форме с аффиксами личной принадлежности имен и причастий. Притяжательные суффиксы те же, что и у существительных.

Самодийские языки (финно-угорская группа) демонстрируют полное совпадение лично-притяжательных суффиксов именительного (основного) падежа с личными формантами глагола в субъектно-объектном спряжении изъявительного наклонения. Указанное сходство показывает их общее происхождение.

В отдельных индоевропейских языках глаголы могут быть основными средствами лексического представления посессивных отношений. Как, например, во французском языке, где доминантным средством выражения обладания является глагол avoir.

В германских языках: в английском и немецком, посессивность также может быть выражена с помощью глаголов.

В языках Кавказа, например, адыгейских и абхазском так же существуют глаголы, содержащие в своей словоформе показатели притяжательности в качестве префиксов. В глаголе могут быть выражены одновременно (в продуктивном залоге) оба лица: и лицо подлежащего и лицо прямого дополнения. Грамматическим средством выражения лиц в глаголе являются личные аффиксы, выступающие всегда префиксами и обозначающие наряду с лицом класс и число субъекта и объекта. Как и в других языках, они восходят к соответствующим личным местоимениям.

Подводя итог вышесказанному, можно сделать вывод, что оформление аффиксами принадлежности имен и глаголов указывает на возможность существования ранее посессивного склонения и спряжения в языках разных систем.

Развитие отношений притяжательности мы увязываем с появлением в человеческом обществе зачатков собственности, на что язык реагирует употреблением дейктических частиц в новой для них функции.

В ряде языков, как например в алеутском, появляется притяжательное сказуемое: для этого используется имя, и к нему присоединяется притяжательная частица - дериват личного местоимения. Подлежащее для 1-го и 2-го лица конкретизируется в самом сказуемом, для 3-го же лица подлежащее ставится в том особом падеже, который указывает здесь на принадлежность ему действия, и который поэтому можно было бы назвать притяжательным падежом. Притяжательное сказуемое содержит в себе указание, во-первых, 
на действующее лицо и, во-вторых, на предмет действия, но только на очень общий предмет. Это сказуемое имеет значение действия, обязательно принадлежащего некоему лицу и переходящего на некий предмет, причем безразлично на какой предмет: алеут. $K^{\prime} a x^{\prime \prime}$ сук ан к" акух. 'Рыба взятие-мое-ее (он) ест'. - 'Он ест рыбу, взятую мною' или 'Он ест рыбу, которую я взял', Адам сук y, буквально: 'Отца взятие его' или по-русски: 'Отец берет'; ср: кет. ba-ta-b-daq 'мое-вытаскивание-этого' (см. Лосев, 1982).

Универсальным средством выражения категории притяжательности постепенно становятся притяжательные местоимения. Во многих языках мира поныне широко используются притяжательные аффиксы, восходящие так же к личным местоимениям. Например, в кабардино-черкесском языке лично-притяжательные формы образуются с помощью префиксальных морфем для 1-, 2- и 3-го лица обоих чисел, путем прибавления их к чистой основе имен существительных: си унэ 'мой дом', уи унэ 'твой дом', йы унэ 'его дом' (см. Кумахов, 1989: 38) и т.д.

Префиксальными элементами, генетически связанными с личными или лично-классными местоимениями, выражается посессивность во всей группе западно-кавказских языков. Ср. адыг. $\boldsymbol{c}$ шъхьэ 'моя голова', каб. $\boldsymbol{y} \sim 2 y$ 'твое сердце', убых. иьь-бза 'наш язык', абх. й-кlyмжуы' его /мужчины/ черкеска', абаз. б-уаса 'твоя /женщины/ овца' [Кумахов, 1989: 40-41].

В кетском языке показатели $-\boldsymbol{b}-, \boldsymbol{- k}-(-\boldsymbol{g}-), \boldsymbol{c} \boldsymbol{d}-$, входящие в структуру личных местоимений (род. падеж), представлены также в притяжательных приставках глагола (табл. 3). 
Таблица 3

\section{Показатели родительного падежа личных местоимений, притяжательных префиксов имен}

и притяжательные местоимения

\begin{tabular}{|l|l|l|l|}
\hline Лицо & $\begin{array}{c}\text { Родит. падеж } \\
\text { личных место- } \\
\text { имений }\end{array}$ & $\begin{array}{c}\text { Притяжат. } \\
\text { префиксы } \\
\text { Имен }\end{array}$ & \multicolumn{1}{|c|}{$\begin{array}{c}\text { Прит-ные } \\
\text { мест-я }\end{array}$} \\
\hline $1-\mathrm{e}$ & $* a-b a$ & $b-$ & $a b^{\prime}$ \\
\hline $2-\mathrm{e}$ & $* u-k u$ & $k-$ & $u k / \gamma^{\prime}$ \\
\hline $3-\mathrm{e}$ м. & $b u-d-a$ & $d a-$ & $b u d a$ \\
ж. & $b u-d-i$ & $d(t)-$ & $b u d i$ \\
вещ. & - & $d(t)-$ & - \\
\hline
\end{tabular}

В качестве притяжательных местоимений генитивные формы личных местоимений встречались в атрибутивном употреблении и в других енисейских языках. В коттском и югском языках эти формы употреблялись, по-видимому так же, как и в современном

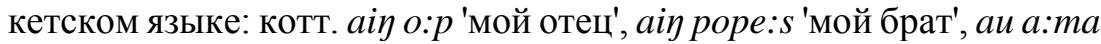

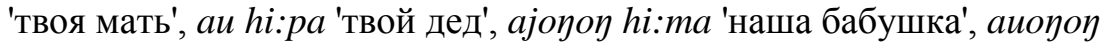
pope:ča 'ваша сестра', иоiayay a:ma 'их мать' и т.д. Они могли также легко заменяться посессивными формами соответствующих имен, как например: yai-teän = yaiteän / aiteän < aij aiteän 'мое желание' (пример М.А. Кастрена).

Большой интерес представляют данные нивхского языка. В один слово-комплекс с именами существительными сливаются здесь личные и возвратные местоимения: $н^{\prime} u$ 'я', ч'u 'ты', $и ф$ 'он', $\mu^{\prime}$ blн 'мы', ч'ын 'вы', имн 'они', n'u 'себя'. Местоимения н'и 'я', ч'u 'ты', $n$ ' $и$ 'себя' опускают в этих случаях свой гласный $u$, а местоимение $u \phi$ 'он' обычно выступает перед гласным в форме в. Образующиеся слово-комплексы выражают значение принадлежности: ылмык 'мать', н'blмык 'моя мать' и'blмык 'твоя мать', в ылмык 'его мать',

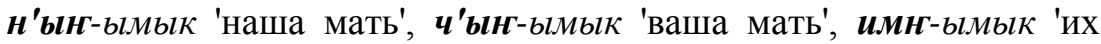
мать', $\boldsymbol{n}$ 'blмык 'своя мать'. Проявление той же системы имеет место и при соединении основы имени существительного с другим именем существительным; например, от слова т'иф 'след', 'тропа', 'дорога', образуются слово-комплексы: к'эq-зиф 'след лисы' (к'эq 'лиса'), qan-д'иф 'след собаки' (qан 'собака') и т. д. (см. Крейнович, 1958: 30). 
В кетском языке могут совершенно свободно образовываться словоформы с глаголом 'делать' (bet-) и инкорпорированием любого существительного в форму ед. или мн. числа, если это возможно семантически. Например: quy-di-vet 'я имею палатку' (букв. 'я с палаткой'), ditl'gat-day-bet 'У нас есть дети' (букв. 'мы с детьми') (см. Крейнович, 1968a: 140-141; Werner, 1997a: 217-219). Этот механизм инкорпорации в современном кетском языке сохранился до сих пор. Особенно продуктивным в этом плане является глагол bet, например: кет. tet-di-vet 'у меня есть муж' (tet 'муж').

Всему именному инкорпорированному комплексу может предшествовать личный притяжательный префикс, образуя с определяемым именем существительным рамку инкорпорированного комплекса. Внутри этой рамки размещается определяющая часть: кет. $\boldsymbol{d a}$-ugdey-bul'ay-s'cl 'его длинноногий олень', na-hol-hut-tip 'их короткохвостая собака' (см. Вернер, 2000: 48). Таким образом, показатель притяжательности входит непосредственно в состав глагольной словоформы, которая доминирует в предложении, а именные члены обычно конкретизируют различные глагольные показатели. 


\section{4. ПРИТЯЖАТЕЛЬНЫЕ ОТНОШЕНИЯ И КАТЕГОРИЯ ВЕРСИИ}

По Г.А. Климову классный строй сменяется активным, который характеризуется противопоставлением не субъектного и объектного начал, как в языках эргативного строя, а противопоставлением активного и инактивного.

Одной из наиболее важных лексических импликаций активного строя является разделение имен существительных на активный и инактивный классы. Классы противопоставляются по признаку наличия или отсутствия у их денотатов жизненной активности. Например, к активному классу относятся имена людей, животных, деревьев и растений; к инактивному - названия всего остального. При этом внутри имен инактивного класса имеется дальнейшие более дробные подразделения, основанные на конкретизации предметов по их форме и другим признакам (например, именная классификация в северно-американских языках на-дене) (см. Климов, 1973: 216), или классификация в енисейских языках (см. Werner, 1994.: 20-23; Поленова, 2011: 24-41).

Подобное распределение именной лексики на классы в тунгусоманьчжурских, меланезийских и других языках напоминает разделение по признаку наличия или отсутствия у них жизненной активности: первый класс - имена неотторжимых объектов, в основном частей тела, имена родства, и т.д., второй класс - остальные имена (см. Климов, 1972 : 3-13). Разделение имен на активные и инактивные группы, а также соответствующее противопоставление групп предикатов и конструкций предложения, является универсальным для естественного языка.

В синтаксисе языков активного строя так же противопоставляются две основные модели предложения - активная и инактивная. Первую модель образуют активные глаголы, вторую - стативные. В соответствии с семантической детерминантой активного строя здесь представлены два падежа - активный и инактивный. Активный падеж оформляет подлежащее при активном глаголе-сказуемом, инактивный - оформляет подлежащее при стативном глаголесказуемом, а также дополнения (некоторые из последних могут принимать послеложные окончания) [Климов, 1977: 159].

Активный падеж в плане выражения противопоставляется инактивному, как маркированный член оппозиции немаркированному. 
По выводам индоевропеистов, во многих индоевропейских языках в более древнюю эпоху был активным, т.е. маркированным падежом, падеж на $-\boldsymbol{s}$ (позднее показатель $-\boldsymbol{s}$ был утрачен) с функцией обозначения деятеля. Падеж без показателя $-s$, т.е. инактивный, указывал лишь на отсутствие обозначения деятеля, ибо был немаркированным как в плане выражения, так и в плане содержания (ср.: Иванов, 1958: 39-40).

Противопоставление активного падежа с характеристикой -t инактивному на $\boldsymbol{- n}>\boldsymbol{\theta}$ отмечено в языках мускоги (Северная Америка). По неподтвержденному мнению К. Уленбека, оно налицо и в личных местоимениях языка дакота, где $m i-s$ 'я' (акт. падеж) mi 'я' (инакт. падеж), $i$-s 'он' (акт. падеж) $i$ 'он' (инакт. падеж). [Климов, $1977:$ 160-161].

О логической связи именной категории притяжательности с активным строем свидетельствует тот факт, что формы органической принадлежности принимают лишь существительные, соотносящиеся с именами активного класса [Климов, 1973: 226]. Обе формы притяжательности действительно различают имена, соотносящиеся в пределах атрибутивной синтагмы только с субстантивами активного класса, а именно: обозначения частей тела и растения, термины родства, названия ряда тесно связанных с человеком и животным реалий. (см. Яковлев, 1941: 40-41).

В ряде языков, например в языках Кавказа, тунгусо-маньчжурских, Меланезии и т.д. и сейчас существуют два вида слов для выражения притяжательности (отчуждаемая-неотчуждаемая), отличающихся своими показателями.

Первый вид - притяжательные префиксы неотчуждаемой, или органической принадлежности. К этому виду относится принадлежность членов и органов тела - всему организму, частей предмета - целому предмету, а также некоторые отношения родства и некоторые пространственные и временные отношения (начало, конец, верх, низ и др.). Второй вид притяжательности - префиксы отчуждаемой, или имущественной принадлежности. Второй вид выражает принадлежность предметов собственности их владельцу.

Развитие КП мы связываем также с таким атрибутом активного строя, как версия.

Версия (от ср.-лат. Versio - видоизменение, поворот) представляет собой грамматическую категорию глагола, обозначающую от- 
ношение действия к его субъекту или косвенному объекту и служащей преимущественно для выражения предназначенности действия. Категория версии встречается в кавказских, семитских, в отдельных индоевропейских и в некоторых других языках. Версия проявляется в том, что диатеза глагола изменяется в зависимости от наличия или отсутствия косвенного дополнения, меняется направленность действия: центростремительность и центробежность. При отсутствии дополнения версия нейтральна по своему характеру (показатели рядов $d i$ - в кетском языке). Если дополнение имеется, то версия центробежна (показатели рядов bo- в кетском языке). Если действие замкнуто на подлежащем, то выражена центростремительная версия (показатели рядов $b a-$ в кетском языке). В роли бенефактива / малефактива или посессора одного из объектов, представленных в том же предложении выступает косвенное дополнение.

Субъектно-объектные показатели в кетском языке впервые были приведены К. Боуда, немецким ениссеистом XX в., и названы по форме 1-го лица ед. числа глагола [Bouda, K., 1957]. Кетская категория версии рассмотрена на фоне теории контенсивной типологии Г.А. Климова в трудах Г.Т. Поленовой [Поленова, 1987] и Г.К. Вернера [Werner, 2004]. Фактически показателями непосредственно версии в кетском языке являются гласные $a$ - направление действия к субъекту; $o / u$ - направление действия от субъекта и $i-$ замкнутость действия в самом субъекте, ср. таблицы 1,2 .

Категория версии могла естественным образом развиться из семантики центростремительных глагольных структур, выражавших направленность действия на субъект, в противоположность структурам, выражавшим центробежную направленность действия от субъекта.

Категория предназначения действия или версии предполагает в силу своей семантики участие в действии или в ситуации, описываемой глаголом, дополнительного лица, которому предназначено данное действие.

Особо тесную связь обнаруживает категория версии с категорией неотчуждаемой принадлежности, выражаемой притяжательным местоимением. 
Конструкции с десигнатом в дательном падеже могут быть часто трансформированы в посессивные конструкции, ср. немецкое предложение (1):

(1) Er hat mir die Hand verwundet, которое может быть трансформировано с сохранением смысла в предложение (2):

(2) Er hat meine Hand verwundet [Гамкрелидзе, Иванов, 1984 : 334, 335 .

Версия проявляется только у активных глаголов и сначала только в сфере 1-го лица, занимая место сразу после показателя активного субъекта $\boldsymbol{b}$-. Формируются вышеназванные ряды показателей $\boldsymbol{b} \boldsymbol{a}$ - и $\boldsymbol{b o}$ - (см. табл. 4).

Таблица 4

Кетские субъектно-объектные показатели группы $D$

\begin{tabular}{|l|l|l|l|l|l|}
\hline Число & Лицо & Классы & \multicolumn{1}{|c|}{ префиксы } & \multicolumn{1}{|l}{ Инфиксы } & суффиксы \\
\hline Ед. & $1-\mathrm{e}$ & & $d i:-k u:-$ & $-d i-/-d-/-t-$ & $-d i$ \\
число & $2-\mathrm{e}$ & & $d u:-d a:$ & $-k u-/-g u-/-k-$ & $-k u-d u$ \\
& $3-\mathrm{e}$ & Муж. & $b i-/ \varnothing$ & $-a-/-o-$ & $-d a$ \\
& $3-\mathrm{e}$ & Жен. & & $-i-/-u-$ & $-a m$ \\
& $3-\mathrm{e}$ & Неодуш. & & $-b-/-m-$ & \\
\hline Мн. & $1-\mathrm{e}$ & & $d i:-$ & $-d a \eta-$ & $-d a \eta-k a \eta$ \\
число & 2-е & & $k u:-d u:-$ & $-k a \eta /-g a \eta-$ & $-a \eta-a m$ \\
& 3-е & Одуш. & $b i / \varnothing$ & $-a \eta-/ o \eta-$ & \\
& 3-е & Неодуш. & & $-b-/-m-$ & \\
\hline
\end{tabular}

У инактивных глаголов дейксис $\boldsymbol{a}$ выражает медиальность действия при субъектном показателе $\boldsymbol{d}$-a. Такие глаголы выражали и выражают сейчас непроизвольное действие или процесс. Сравним:

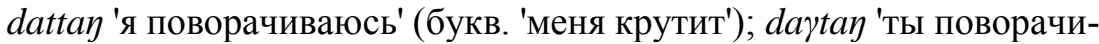
ваешься' ('тебя крутит'); dayetay 'он поворачивается' ('его крутит') и т.д.: bay ul dakajnam 'всюду затоплено' ('землю вода взяла') vqa dakajnam 'я слова не мог вымолвить' ('мои слова взяло') koyot da-tajaja-qirit 'я проголодаюсь' (букв. 'голодом меня потянет') [Поленова, 2011: 203].

Классный показатель активности действия субъекта 'b' приобрел значение центростремительной версии в форме активного глагола. По Г.Т. Поленовой, ему противостоял показатель ' $q$ ' как выразитель центробежной версии. По А.П. Дульзону ' $q$ ' указывало на 
распространение действия за пределы активного актанта [Дульзон, 1968: 145].

Третья версия, представленная показателем 's', выражала нейтральность, объективность действия по отношению к субъекту.

Категория нейтральной версии (морфема $-s^{\prime}$ ), возникла из нейтрального показателя предикативности $s$ ' $i$, исконное значение которого «быть, стать». Первичной функцией $s$ ' $i$ было указание на состояние агенса и на предикативность той словоформы, к которой присоединяется этот аффикс. С оформлением глагола как части речи морфема $s^{\prime}$ приобретает характер нейтральной версии, обозначение состояния или действия, процесса как такового без подчёркивания роли агенса или пациенса ср.: d'an' s 'on 'ijuks'a 'трава зеленеет' [Поленова, 2011: 53].

Версионные показатели не связаны с лицом субъекта и поэтому они проходят через всю парадигму глагола, не меняясь со сменой личного показателя субъекта или объекта [Поленова, 2011: 154 $155]$.

По мнению В.Г. Шабаева, показатели рядов $b \boldsymbol{a} / \boldsymbol{a}$ или $\boldsymbol{b} \boldsymbol{a} / \boldsymbol{b} \boldsymbol{u}(1-\mathrm{e}$ и 3-е лицо) маркируют статический актант, а показатели рядов $b \boldsymbol{o} / \boldsymbol{o}$ или $b \boldsymbol{o} / b \boldsymbol{u}$ - динамический [Шабаев, 1984: 59; Поленова, 2011: 166].

Совпадение глагольных показателей группы $\boldsymbol{B}$ с аффиксами родительного падежа местоимений и имени позволило сделать вывод о едином происхождении показателей группы $\boldsymbol{B}$, а именно, что они генетически являются местоименными показателями субъекта действия при активном глаголе [Вернер, 1974: 41].

Глагольные показатели группы $\boldsymbol{D}$ совпадают с предикативными аффиксами имен, т.е. с аффиксами, оформляющими лексемы состояния субъекта действия, ср.: югск.

$\begin{array}{ll}\text { fen'a'di 'я маленький', } & \text { dijfty 'я пухну' } \\ \text { fen'a'gu 'ты маленький' } & \text { kujft } \eta \text { 'ты пухнешь' } \\ \text { fen'a'da 'она маленькая' } & \text { dajfty 'она пухнет' } \\ \text { fen'a'du 'он маленький' } & \text { dujfty 'он пухнет' }\end{array}$

Глагольные показатели группы $\boldsymbol{D}$ могут быть возведены к форме абсолютного падежа личных местоимений.

Центробежная и центростремительная версии представлены показателями активной серии (показателями $\boldsymbol{B}$ ).

В современных енисейских языках - кетском и югском - показатели $\boldsymbol{B}$ и $\boldsymbol{D}$ могут выступать как в роли субъектных, так и в роли 
объектных [Успенский, 1968 : 210]; порой они свободно взаимозаменяются, например: южн.-кет. en-ba-x'uk - en-di-s'uk 'я-забуду'. Факты подобной функциональной неотдифференцированности глагольных форм с показателями $\boldsymbol{B}$ и $\boldsymbol{D}$ уже сами по себе позволяют предполагать, что различие между ними связано с определенными реликтовыми явлениями в морфологии глагола.

Исторически устанавливается, что гласный $\boldsymbol{- a}$ - связан с лицом говорящего (Ich-Deixis), -и- со 2-м лицом (Du-Deixis), по К. Бругману [Brugmann, 1904] (ср. основной падеж кетских личных местоимений: $\boldsymbol{a} d$ 'я', $\boldsymbol{u} \boldsymbol{k}$ 'ты'); в то же время локальным дейксисом 1-го лица является гласный $-\boldsymbol{i}$-, cp. частицы $d \boldsymbol{i}-d \boldsymbol{u}-d \boldsymbol{a}$, выполняющие в современном кетском языке функции именных предикативных аф-

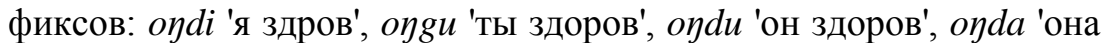
здорова' и т.д. (см. табл. 3). Эти же форманты появляются в роли субъектных глагольных показателей группы $\boldsymbol{D}$, например:

$\begin{array}{llll}d i-\gamma-a q & \text { 'я выйду' } & d i-\gamma-\hbar \text {-an } & \text { 'мы выйдем' } \\ k u-\gamma-a q & \text { 'ты выйдешь' } & \kappa u-\gamma-a \hbar-a n & \text { 'вы выйдете' } \\ d u-\gamma-a q & \text { 'он выйдет' } & d u-\gamma-a \hbar-a n & \text { 'они выйдут' } \\ d \varkappa-\gamma-a q & \text { 'она выйдет' } & & \end{array}$

Таким образом, сфера «я, здесь, сейчас» оказывается выраженной, с одной стороны, гласным $\boldsymbol{a}: \boldsymbol{a} d$ 'я', а с другой стороны, гласным $\boldsymbol{i}$ в предикативных и субъектных показателях. Мы придерживаемся точки зрения, что «... первичная форма личного местоимения 1-го лица была $\boldsymbol{a}, 2$-го - $\boldsymbol{u}$, а форма 3-го лица $\boldsymbol{b} \boldsymbol{u}$ восходит к указательному местоимению» [Живова, 1978]. То есть, комплекс $\boldsymbol{a}+\boldsymbol{d i}>\boldsymbol{a d i}$ выражал состояние, неактивность 1-го лица, а $\boldsymbol{a}+\boldsymbol{b} \boldsymbol{a}>$ $\boldsymbol{a b a}$ - активность [там же], его заинтересованность в действии или предмете, его причастность к ним.

Согласные $\boldsymbol{k}$-, $\boldsymbol{t}$-, $\boldsymbol{q}$-, неся информацию о классе денотата, в своей первичной функции, приобрели значение уточнителя степени удаленности от центра ситуации. Сам же этот центр выражался звуком $\boldsymbol{b}$. Так позволяет думать сравнение местоимения bin 'сам' и $\boldsymbol{k i}$ 'этот'. Схематично это можно представить следующим образом (см. схему 3 ) 
Схема 3

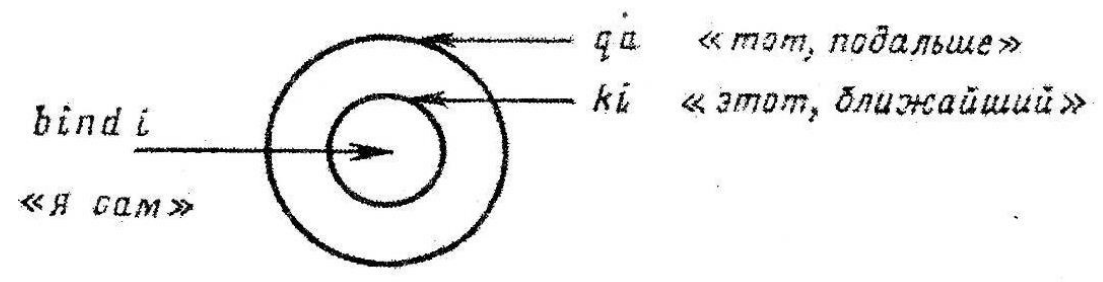

[Поленова, 2011: 168].

Из рядов группы $\boldsymbol{B}$ ряды $\boldsymbol{b} \boldsymbol{a} / \boldsymbol{a}$ и $\boldsymbol{b} \boldsymbol{o} / \boldsymbol{o}$ наиболее древние, первичные по отношению к рядам $b a / b u$ и $b o / b u$. Это связано с грамматикализацией классного показателя $\boldsymbol{b}$. С одной стороны, он становится выразителем неживого, вещного класса, а с другой, формирует личное местоимение 3-го лица $\boldsymbol{b} \boldsymbol{u}$ 'он, она', которое в составе глагола выражает идею, что действие совершается для субъекта (им же самим для себя, над собой), например:

$\begin{array}{llll}b a-t-o \kappa & \text { 'я-вздрогну' } & b a-\eta-s-u-R o & \text { 'я-смотрю' } \\ k u-t-o k & \text { 'ты-вздрогнешь' } & k u-\eta-s-u-R o & \text { 'ты-смотришь' } \\ b u-t-o k & \text { 'он-вздрогнет' } & b o-\eta-s-u-R o & \text { 'он-смотрит' }\end{array}$

Таким образом, нам представляется, что форманты кетского глагола $\boldsymbol{b}$ и $\boldsymbol{q}$ являются реликтовыми уточнителями версии, а именно: $\boldsymbol{b}-\boldsymbol{v}-\boldsymbol{m}$, выражает центростремительность, замкнутость действия на активном актанте-субъекте, т. е. что оно выполняется для него или принадлежит ему, внутренне присуще ему, сосредоточено в нем. Ср.:

\section{Настоящее-будущее} время

$d i-v$-ä-ris' 'я-бранюсь' $\kappa u$-v-ä-ris' 'ты-бранишься' $d u-v-\ddot{a}-r i s^{\prime} \quad$ 'он-бранится' $d a-v$-ä-ris' 'она-бранится'

\section{Прошедшее завершенное} время

$b-i-l^{\prime}-d i s^{\prime}$

b-il-gu-ris'

$b-i-l$ '- $a-r i s^{\prime}$ $d a-b-i-l l^{\prime}-a \ddot{a}-r i$ 'я-бранился'

'ты-бранился'

'он-бранился' 'она-бранилась'

[Поленова, 2011: 173]

Следует отметить, что центробежная и центростремительная версии, выраженные глагольной формой существуют и в других языках древнего образования, в частности, в адыгейском языке, в 
языках индейцев Америки, где имеются две категории притяжания, полисинтетический глагол, и две конструкция предложения (ср. Яковлев, 1941 : 40-41).

Таким образом, семантической детерминантой активного строя является противопоставление активного и инактивного в языке.

Активный строй отличается так же наличием двух, характерных для него моделей предложения - активной и инактивной.

В языке существуют два вида принадлежности: имущественная (отчуждаемая) - органическая (неотчуждаемая). Различие между ними заключается в отсутствии или присутствии соответственно посессивного маркера.

Активный глагол различает формы центробежного («отчуждаемого») и нецентробежного («неотчуждаемого») действия, из которых развивается категория версии.

Показатели версии, вошедшие в состав глагольной словоформы, а также в состав личных и притяжательных местоимений, трансформировались в показатели притяжательности. 


\section{5. ПРИТЯЖАТЕЛЬЫЙ «СТРОЙ» КАК ОДИН ИЗ ЭТАПОВ РАЗВИТИЯ ЯЗЫКА В РАМКАХ ЭРГАТИВНОГО СТРОЯ}

Эргативная конструкция предложения, называемая так по маркированному падежу, вовсе не является каким-то маргинальным синтаксическим явлением: она зафиксирована во многих языках различной генетической принадлежности, находящихся на различных континентах (см. Кибрик А.Е.).

Накопленный материал по различным языкам, использующим эргативную конструкцию, показал, что эти языки, в свою очередь, синтаксически чрезвычайно разнообразны. Так, если в одних языках (например, в нахско-дагестанских) эргативная конструкция является жестким способом кодирования ядерных актантов, зависящим исключительно от управляющих свойств глагола, в других языках (например, в картвельских, индейских) она ограничена определенными временными формами глагола (обычно планом прошедшего времени), в третьих (например, в чукотско-камчатских, австралийских языках) эргативная конструкция при переходных глаголах допускает преобразование, аналогичное пассиву аккузативных языков. Далее, если в одних языках, имеющих эту конструкцию, наблюдается сходство синтаксического поведения номинатива непереходного глагола с эргативом переходного (т.е. субъекта - в терминах аккузативных языков), то в других языках такого сходства не наблюдается. Наконец, более детальное описание ряда языков, относившихся ранее к эргативным, показало, что не во всех из них реализована именно эргативная конструкция. Кроме аккузативной и эргативной, возможны и другие конструкции ... (см. Кибрик, а также Филлмор Ч.).

При внимательном анализе, оказывается, что эргативная конструкция, засвидетельствованная в материале в прошлом и конструкция в настоящем имеют различия (см. Кацнельсон С.Д., Пирейко Л.А. и др.). Не случайно в языкознании появился термин эргативообразные конструкции.

В настоящий момент среди ученых-языковедов существует мнение, что различные виды конструкций, а именно: абсолютные, аффективные, эргативные и посессивные могут относиться к одному и тому же строю языка (И.И. Мещанинов, Г.А.Климов, 
И.А. Мельчук, Г.К. Вернер, Г.Т. Поленова и др.), а именно: эргативному.

Эргативная конструкция, таким образом, есть частный случай (синтаксической) предикативной конструкции, т.е. конструкции "подлежащее - сказуемое", посессивная конструкция - это модель посессивного предложения эргативной типологии (см. Краснощеков, 2013:136-143; Челябинск, 2013: 25-29;. Таганрог, 2016).

Реликты посессивного строя заметны в енисейских языках. Развивая наблюдения М. Кастрена и Н.К. Каргера, И.И. Мещанинов отмечал, что в кетском глаголе частично улавливаются признаки притяжательного строя спряжения [Мещанинов, 1948: 509]. Эту идею позднее развил Е.А. Крейнович, который предположил, что в кетском "... генетические показатели группы $\boldsymbol{B}$ указывали не на субъект действия, а на принадлежность действия лицу: batabdak 'мое-вытаскивание-этого' (а не 'я-вытащу-это'), подобно тому, как префикс 1 л. ед. ч. именной категории притяжательности указывает на принадлежность вещи лицу: bam, также abam 'моя мать' (am 'мать') и т.д. [Крейнович, 1968: 24].

Представляется, что и субъектно-личные форманты группы $\boldsymbol{D}$ следует возводить к посессивной структуре енисейских слов-синкретов, к позднеактивному периоду, когда стали размежевываться имя и глагол. Ср.: es'ta qAmejbata 'гром гремит' (es' 'бог, гром'., -ta $<d a$ - окончание родительного падежа муж. кл.); hən'a qoks'di s'anejbata 'ручей шумит' (qoks' 'ручей', -di - окончание род. пад. жен. кл.); ср.: tap de:s ab bayabda 'собачий лай я слышу' ( $a b$ 'мой').

Показатели группы $\boldsymbol{B}$ выражали органическую принадлежность не только предмета, но и действия, а показатели группы $\boldsymbol{D}$ неорганическую принадлежность предмета, признака действия, состояния, ср. исходные формы местоимений $a d$ 'я', $a b$ 'мой' > *adi и *aba в кетском языке.

Полагаем, что первичное енисейское сказуемое не было глаголом, оно выражало состояние субъекта с помощью предикативных показателей, а активное действие путем присоединения притяжательных приставок.

Глагол получил притяжательное оформление одновременно с именем. Посессивные аффиксы с развитием грамматического строя языка стали при именах обозначать принадлежность, а при глаголах - лицо субъекта, совершающего действие, и объекта, на который 
данное действие направлено. Те и другие форманты местоименного происхождения [Поленова, 2011: 43-44; Живова, 1978,].

Посессивные парадигмы имеют в кетском языке глаголы, обозначающие различные звуки, шумы и физические ощущения. Восприятие шума может возникнуть вследствие наличия звучащего предмета. При таком осмыслении факта звучания это явление в кетском языке обозначается посессивно, то есть, шум рассматривается как принадлежность предмета.

По мнению Г.К. Вернера глаголы звука и шума - это бывшие именные притяжательные формы в сочетании со вспомогательным глаголом (сp. Werner, 1997: 187). Восприятие шума может быть осмыслено как результат преднамеренного действия того или иного лица, которое может его производить для себя (возвратнопереходное спряжение напоминает глагольную версию) или для воздействия на других (переходное спряжение). У глаголов, обозначающих звуки и шорохи (Verba sentiendi) в енисейских языках, субъектная функция выражается с помощью посессивных префиксов, так как эти формы представляют собой переосмысленные бывшие именные поссесивные формы в сочетании с вспомогательным глаголом; p-kutal'ejbeta 'я свищу' < 'мой свист слышится ', pkulol'ejbil'sta 'я свистел'< 'мой свист слышался'. При этом префиксы притяжательности могут заменяться полными притяжательными местоимениями в современном кетском языке: at ab ^yajbata'я ворчу' (букв. 'я-мое-ворчание') и т.п. Не возникает сомнения, что эти «образования» в современном кетском могут причисляться к глагольным формам, так как они содержат аффиксы времени и «аспектуальности». Их также можно считать притяжательными формами Совершенно очевидно, что енисейский глагол хранит в себе признаки посессивной типологии [ср.: Поленова, 2008: 213].

О возможности существования в древности притяжательного строя (периода) в языках писал ряд кетологов и ученых-языковедов (Кастрен М.А., Мещанинов И.И., Финк Н. 1950; Шухардт Г. 1950; Lewy Bruhl 1961 и др.). Эту точку зрения разделял также Вяч. Всев. Иванов, (см. работу Категория посессивности в славянских и балканских языках. М.: Наука. 1989). Под языком посессивного типа имеется в виду такой язык, где не только притяжательные отношения между обладаемым и обладателем, но и другие типы грамма- 
тических отношений (ролевые - "актактные" валентности, локативные [см. КПСБЯ, 1989; Seiler, 1983], могут выражаться посредством притяжательных форм.

Примером может служить адыгейский язык. Личные префиксы глагола здесь по происхождению представляют собой притяжательные префиксы неотчуждаемой принадлежности, но в 3-м л. мн. ч. используется префикс отчуждаемой принадлежности; при выражении локативных отношений посредством пространственных имен-послелогов используются аффиксы неотчуждаемой принадлежности (bl-бгъу 'сбоку от него', bl-ч 1 эгъ 'под ним', букв. 'его нижняя сторона' и т.п.).

Признавая наличие в прошлом енисейских языков притяжательной конструкции, мы считаем, что речь идет об одном из периодов развития языка в рамках эргативного.

Вышеизложенное позволяет сделать следующие выводы:

Эргативная конструкция предложения, не является маргинальным синтаксическим явлением: она зафиксирована во многих языках различной генетической принадлежности, находящихся на различных континентах.

Посессивная конструкция - это модель посессивного предложения эргативной типологии.

Под языком посессивного типа подразумевается язык, где не только притяжательные отношения между обладаемым и обладателем, но и другие типы грамматических отношений (ролевые "актактные" валентности, локативные), могут выражаться посредством притяжательных форм.

В формах отчуждаемой и неотчуждаемой принадлежности аффиксы, совпадающие с формами неотчуждаемой принадлежности, обычно характеризуют глаголы субъектного спряжения, аффиксы отчуждаемой принадлежности глаголы объектного спряжения. 


\section{6. ТРАНСФОРМАЦИЯ ЭЛЕМЕНТОВ КАТЕГОРИИ ПРИТЯЖАТЕЛЬНОСТИ ПРИ ПЕРЕХОДЕ ОТ ЭРГАТИВНОЙ СТРУКТУРЫ ЯЗЫКА К НОМИНАТИВНОЙ}

Различный темп изменения и развития языков является общеизвестным фактом. Для диахронического исследования очень важен материал языков «застывших» в своём развитии и сохранившие черты наиболее древней структуры языка. Это, прежде всего, языки бесписьменные и изолированные от большой цивилизации, типа: бурушаски, баскского, дагестанских, индейских, африканских, австралийских и енисейских языков. Интересно, что те лингвисты, которые уходят от диахронии и стадиальности в эволюции языка, так или иначе, группируют языки по степени их развития. Г.П. Мельников, например, выработал свою «Системную типологию языков» на синхронном уровне, синтезируя морфологическую классификацию языков со стадиальной, базируясь на положениях В. Гумбольдта, А.А. Потебни и И.А. Бодуэна де Куртенэ, который, в частности, писал: «Для того, чтобы составить себе хоть приблизительное представление о первобытном состоянии языка вообще, очень поучительно исследовать языковое состояние дикарей. Если исследователю невозможно совершить это посредством собственного наблюдения, он должен черпать свои сведения из лингвистических трудов других учёных и из достоверных описаний путешественников (что мы и делаем в нашем исследовании - Е.К.)» [Бодуэн де Куртенэ, 2010 : 20]. Г.П. Мельников ставит существование различного строя языков в зависимость от изменений номинативного ракурса («тема» - «рема» предложения-высказывания) в коллективе определённой величины: инкорпорированные языки микроколлективы (племена охотников-собирателей), эргативные языки - макроколлективы и номинативно-аккузативные флективные языки - мегаколлективы. Г.П. Мельников провёл очень содержательный анализ языков четырёх морфологических типов, выделенных ещё В. Гумбольдтом [Мельников, 2000: 73]. Отдавая должное его работе, мы взяли у тех же учёных, на которые опирался Г.П. Мельников, идею постепенного развития языка от «односложности» через «агглютинацию, или свободное сопоставление» к 
«флексии», говоря словами Бодуэна де Куртенэ, который сравнивал славянские языки, делая общелингвистические выводы [Там же: с. 22-25; 82]. Мы отталкивались, как и наши предшественникикетологи Г.К. Вернер и Г.Т. Поленова, от контенсивной типологии Г.А. Климова, который представил типологию развития языка в следующем виде:

Таблицуа 5

\section{Типология развития языка по Г.А. Климову}

\begin{tabular}{|c|c|c|c|c|c|c|}
\hline & & $\begin{array}{c}\text { Нейтраль- } \\
\text { ный }\end{array}$ & Классный & Активный & Эргативный & Номинативный \\
\hline Лексика & $\begin{array}{l}\text { Существи- } \\
\text { тельное } \\
\text { Глагол }\end{array}$ & $?$ & $\begin{array}{l}\text { Множество } \\
\text { предм. классов } \\
\text { Ситуац. } \\
\text { качеств (?). }\end{array}$ & $\begin{array}{l}\text { Активн. } \\
\text { инакт. классы } \\
\text { Активн. } \\
\text { стативн. }\end{array}$ & $\begin{array}{l}\text { Ø } \\
\text { Транзит. } \\
\text { интранзит. }\end{array}$ & $\begin{array}{l}\varnothing \\
\text { Транзит. } \\
\text { интранзит. }\end{array}$ \\
\hline $\begin{array}{l}\text { Синтак- } \\
\text { сис }\end{array}$ & $\begin{array}{l}\text { Конструкции } \\
\text { предложения } \\
\text { Дополнения }\end{array}$ & $\begin{array}{l}\text { Нейтральная } \\
\text { Единое }\end{array}$ & $?$ & $\begin{array}{l}\text { Активн. } \\
\text { инактивная } \\
\text { Ближайш. } \\
\text { Дальнейшее }\end{array}$ & $\begin{array}{l}\text { Эргативн. } \\
\text { абсолютная } \\
\text { Прямое } \\
\text { косвенное }\end{array}$ & $\begin{array}{l}\text { Номинативная } \\
\text { Прямое кос- } \\
\text { венное }\end{array}$ \\
\hline $\begin{array}{l}\text { Морфо- } \\
\text { логия }\end{array}$ & $\begin{array}{l}\text { Именное } \\
\text { склонение } \\
\text { Глагольное } \\
\text { спряжение }\end{array}$ & $\varnothing$ & $\begin{array}{l}\text { Ø } \\
\text { Множество } \\
\text { классно- } \\
\text { личных } \\
\text { аффиксов } \\
\text { (дейктических } \\
\text { частиц, } \\
\text { партикул - } \\
\text { Е.К.) }\end{array}$ & $\begin{array}{l}\text { Активн. } \\
\text { инакт. пад. } \\
\text { Активн. } \\
\text { инакт.ряды } \\
\text { личных } \\
\text { аффиксов }\end{array}$ & $\begin{array}{l}\text { Эргативн. / } \\
\text { абсол. пад. } \\
\text { Эргат. } \\
\text { абсолют. } \\
\text { ряды личных } \\
\text { аффиксов }\end{array}$ & \\
\hline
\end{tabular}

[Климов, 2009: 291]

В позднеактивном состоянии языка происходит ослабление противопоставления по классам активных и инактивных. С этим связаны наблюдающиеся в его представителях случаи стирания оппозиции форм органической и неорганической принадлежности в посессивной флексии имен существительных (см. Климов, 1977: 202; см. также Кумахов, 1989: 39).

Процесс снятия противопоставления между двумя притяжательными формами принадлежности в именной морфологии является характерным для языков эргативного строя. Категория притяжательности становится выразителем подлинно посессивных отношений, предполагающих как субъект, так и объект обладания (см. Климов, 1977: 202). Соответствующая формальная оппозиция постепенно нейтрализуется во все более обширной группе субстанти- 
вов. Одновременно формируется унифицированная категория притяжательности, типа представленной в абхазском, или в таких номинативных языках, как тюркские или уральские. Иногда этот процесс сопровождается обобщением формы органической принадлежности, иногда - неорганической.

Так, в абадзехском диалекте адыгейского языка наблюдается использование префиксов отчуждаемой и неотчуждаемой принадлежности на уровне вариантов, т.е. как факультативные формы одного и того же слова, закрепленного лишь за префиксами неотчуждаемой принадлежности в других адыгейских диалектах. Ср. абадз. сын(э) - син(э) 'мой глаз', сылу - сигу 'мое сердце', спэ - сипэ 'мой нос', ыббъъ - йыбгъъ 'его грудь', ыпшъэ - йыпшъэ 'его шея', ыюбз йыбзэ 'его язык'. Подобное варьирование форм принадлежности свидетельствует о том, что в диалектах протекает процесс преобразования форм неотчуждаемой принадлежности в формы отчуждаемой принадлежности.

В языке анатолийских шапсугов процесс нейтрализации форм отчуждаемой и неотчуждаемой принадлежности протекает более интенсивно, чем в других адыгейских диалектах.

Вместе с тем в развитии категории посессивности наблюдаются разнонаправленные тенденции в одной и той же диалектной среде. Так, в диалекте причерноморских шапсугов отмечается обратное явление: расширение круга имен существительных, характеризующихся формами неотчуждаемой принадлежности: шапс. уылъъэрал, адыг. лит. уиккъэрал 'твое государство', шапс. уышыьхэр, адыг. лит. уишхэр 'твои лошади', шапс, тымылькку, адыг, лит. тимыльку 'наше имущество', шапс. уысээъффуэ, адыг. лит. уисэшхуэ 'твой меч' [Керашева, 1957: 63; Кумахов, 1989: 39].

В этом плане определенную эволюционную схему для большей части северно-американских языков представил К. Уленбек. Он писал в одной из своих работ: «... исходя из того, что мы наблюдаем в архаических языковых типах Северной Америки, я склонен думать, что наименования частей тела в языках сравнительно новой формации, например, в языках юкки и помо, некогда трактовались так же, как и названия родства, но позднее по аналогии с названиями отчуждаемых объектов они стали трактоваться уже как последние» [Уленбек, 1950: 189; Климов, 1973 : 193-194]. 
В абхазском языке версионный показатель -з- выражает не только предназначенность действия субъекта объекту; в переходных глаголах -з- выражает принадлежность прямого объекта косвенному. Например: Акамбашькуа уака ианиасиалакь ачкунцуда и-с-зыршьа$x a n$ - 'Когда буйволов туда погоню, мальчики ноги им перевяжут (для меня)'. В глаголе $u$-c-зыршь $a-x a n$ 'они для меня что-то перевяжут' $\boldsymbol{p}$ - является показателем субъекта, $\boldsymbol{c}$ - - косвенного объекта (я), $\boldsymbol{u}$ - - прямого объекта (ноги), з- - версионным показателем, который показывает, что, благодаря действию субъекта, прямой объект предназначается косвенному, т. е. «реляция идет от прямого объекта к косвенному (u-c-зы-p-uьaхаn)» [ГАЯ, 1968: 140].

С течением времени субъектно-объектные отношения стали постепенно вытеснять оппозицию активный/инактивный. Доминирующими субъектными показателями становятся лично-субъектные префиксы стативных глаголов, о чем свидетельствуют, например в кетском языке, случаи наращивания аффиксов группы $\boldsymbol{D}$ перед объектными аффиксами группы $\boldsymbol{B}$ (ср.: $d$-a-tuך 'он его видит', 'd-i-tuך 'он ее видит').

Так, в ряде языков оказывается возможной передача отношений органической принадлежности показателем нецентробежной версии в словоформе глагола. Например, в языке хидатса (Сев. Америка), где функционируют построения типа waceo ki-aara-ikao-c 'человек свою/себе руку увидел', в котором $k i$ - является префиксом нецентробежной версии (ср. принципиально сходный способ выражения органической принадлежности в картвельских, а также в некоторых древних индоевропейских языках) [Климов, 1977: 202].

Нейтрализация противопоставления двух форм категории принадлежности наблюдается в абхазско-адыгских языках. В адыгейском языке, в котором рассматриваемая оппозиция еще действует, она используется весьма непоследовательно. Так, «...те термины родства, которые происходят от возрастных обозначений и которые поэтому могут быть употреблены не только родственниками, но и другими лицами, например, жителями одного села по отношению друг к другу, выражаются префиксами неорганической принадлежности. Например: ... cu-кlaлэ 'мой мальчик, сын', сuпшъаш/ъэ 'моя девушка, дочь', си-шъао 'мой ребенок, сын'» [Яковлев, Ашхамаф, Грамматика адыгейского языка. 1941: 297; в нашей работе мы использовали также грамматику адыгейского языка (ав- 
тор У.С. Зекох), изданную в 2002 году, но в интересующих нас разделах, автор постоянно ссылается на работу Н.Ф.Яковлева и Д.А.Ашхамаф, поэтому мы решили воспользоваться ей как первоисточником]. Более того, этими же префиксами в адыгейском языке ныне передаются отношения «принадлежности» старших родственников младшим: ср. сян (cu-aн) 'моя мать', сят (cu-am) 'мой отец', сянежъ (си-анэжъ) 'моя бабушка', а также отношения свойства: ср. си-нысэ 'моя невестка', си-гуащэ 'моя свекровь', сишъуз 'моя жена' и т.п. [Яковлев, Ашхамаф, 1941: 298].

На этом фоне тем более интересными представляются факты словоизменения по формам органической принадлежности, которые отмечаются у имен, обозначающих части деревьев и растений. Например 'лист', 'корень', 'стебель' и т.п. Пережитки, более систематически проводившегося в прошлом различения притяжательных форм органической и неорганической принадлежности, засвидетельствованы и в бесленеевском диалекте кабардинского языка [Климов, $1973: 194]$.

Реликты противопоставления рассматриваемых форм прослеживаются в отдельных нахско-дагестанских языках. Например, в даргинском языке обращает на себя внимание небольшая группа субстантивов, обозначающих части тела и постоянно употребляющихся в притяжательной форме, которая варьирует по категории класса: в-/, p-/, б-/ д- $а x$ 'лицо (мужчины, женщины, животного, вообще)', в-/, p-/, б-/, д-арг 'желудок (мужчины, женщины, животного, вообще), в-/, p-/, б-/, д-айъ 'поясница (мужчины, женщины, животного, вообще)'. На архаичность этих образований указывает факт использования в роли соответствующих экспонентов классных, а не личных аффиксов [там же Климов, 1973:195].

В тунгусо-маньчжурских языках, несмотря на наличие двух форм принадлежности, большая часть существительных может оформляться как конструкциями неотторжимой принадлежности, так и конструкциями отторжимой принадлежности. Например, в удэгейском 'языке diлi-нi 'его голова' (часть тела) - diлi-нi-нi 'его голова (принадлежащая ему голова убитого зверя, рыбы)' в эвенском языке hymъ-н 'его сын' - hymb-н-н 'тот, который считается его сыном' (приемный сын); в нанайском языке боло ини-ни 'день осени' ини-нгу-пу 'наши дни' [Камова, 1981: 57]. 
Случаи варьирования в притяжательном оформлении лексем наблюдаются и в языках Меланезии. Так, имена частей целых могут употребляться как в конструкциях неотторжимой принадлежности, так и в различных конструкциях отторжимой принадлежности в зависимости от своей референции, например, в языке мота: na pane-k 'моя рука', -no-k о рапе 'мой браслет' (na, o - артикли, - $\boldsymbol{k}$ местоименный суффикс I л. ед. ч., 'nо- показатель общей отторжимой принадлежности); в фиджи: $\boldsymbol{n a}$ uto-mu 'твое (собственное) сердце;' - na по-ти иto 'твое (чье-то) сердце', - na ke-ти иto 'твое сердце' (для еды) (na артикль,-mu- местоименный суффикс 2 л. ед. ч., $\boldsymbol{n o}$ - показатель общей отторжимой принадлежности, $\boldsymbol{k e}$ - показатель принадлежности пищи). Существительные, значение которых содержит, например, сему 'съедобность', оформляются обычно конструкцией "для еды": в языке мота ga-k o vetal 'мой банан' (для еды), в языке суау $n$-gu udo 'моё таро' (для еды). Однако, если обладатель рассматривает денотаты таких имён как общую принадлежность, которую он не собирается сам потреблять, а намерен, например, хранить ее или продать, должна быть использована конструкция общей отторжимой принадлежности: в языке мота no-k o vetal 'мой банан' (собственность), в суау $e$-gu udo 'мое таро' (собственность). С другой стороны, в конструкции 'для еды' могут встречаться и имена, значение которых, вообще говоря, не содержит семы 'съедобность', и которым эта сема приписывается окказионально [Камова, 1981: 61].

Полагаем, что сохранение или исчезновение двух форм принадлежности может быть связано с былым существованием версионной диатезы активного глагола. В процессе изменения языка активный глагол преобразуется в субъектно-объектный глагол в эргативных и номинативных языках. В эргативных языках наступает полная редукция незалоговой диатезы глагола - версии в посессивной флексии имен. В связи с этим сохраняется противопоставление форм органической и неорганической принадлежности. В языках номинативных, где незалоговая диатеза сохраняется, версия перерастает в залоговую. Притяжательные отношения дольше передаются в глагольной словоформе. Это способствует ускоренной нейтрализации такого противопоставления в именной морфологии [Климов, 1977: 203]. 
В ходе дальнейшей эволюции в именной морфологии языков наблюдается тенденция к развитию падежной системы. К средствам выражения категории притяжательности, различающей две формы принадлежности, добавляется категория падежа.

На позднем этапе функционирования эргативности в парадигме склонения языков появляются генитив и датив как падежи, специально ориентированные на передачу субъектно-объектных отношений. К этому времени генитив и датив сформировались в баскском, нахско-дагестанских, хурритско-урартских языках. В другом древнем языке Передней Азии - шумерском, судя по всему, засвидетельствована фаза становления обоих. В соответствии с широко известной закономерностью генитив приходит здесь на смену посессивной флексии имени. «В шумерском языке, - пишет А.П. Рифтин, - есть конструкции типа e melam-bi 'храм - блеск его' = 'блеск храма', e-e lugal-bi 'этот храм - царь его' = 'царь этого храма' ... Появление родительного падежа ... приводит вскоре в шумерском к другой конструкции lugal e-a (k) 'царь дома'» [Климов,1973: 190].

Сходная картина зафиксирована в языке бурушаски, где родительный падеж знают лишь субстантивы второго лексического класса (при функционировании здесь именной категории притяжательности). Парадигматизация специальных окончаний родительного и дательного падежей также проходит через ступень функционально «совмещающих» падежей, прежде всего - эргативно-общекосвенного. В этом отношении весьма показательно, что в некоторых случаях генитив и датив могут рассматриваться как производные от последнего не только в функциональном, но и в формальном плане: ср. аварск. вац-ас-ул 'брата' и вац-ас-е 'брату' при форме эргатива вац-ас, лезг., буба-ди-н 'отца', буба-ди-з 'отцу' при форме эргатива бубй-ди [там же].

Таким образом, в позднеактивном состоянии языка происходит ослабление противопоставления субстантивов по классам активных (одушевленных) и инактивных (неодушевленных), что приводит к стиранию оппозиции форм органической и неорганической принадлежности.

К категории притяжательности, различающей две формы принадлежности, присоединяется категория падежа.

Сохранение или исчезновение двух форм принадлежности может быть связано с былым существованием версионной диатезы активного глагола. 
C возникновением унифицированной категории притяжательности оказывается возможной передача отношений органической принадлежности показателем нецентробежной версии в словоформе глагола.

Таким образом, материал рассмотренных языков представляет нам процесс трансформации и утраты противопоставления между двумя притяжательными формами принадлежности в именной морфологии. Этот процесс проявляется в постепенной нейтрализации соответствующей формальной оппозиции во все более увеличивающейся группе имен существительных. В дальнейшем возникает унифицированная категория притяжательности (органической + неорганической), как, например, в абхазо-адыгских языках, в тюркских, уральских и других. 


\section{ВЫВОДЫ}

Существующие между языками различия не исключают существенной общности языков, позволяющей рассматривать различные языки как представителей одного рода - человеческого языка. С учетом общего, что существует у людей земного шара, различия составляют лишь незначительную долю. Это является главной причиной фиксирования в языках огромного количества общих понятий, хотя и разными языковыми способами. Одним из таких понятий в языке является категория притяжательности.

Основная причина изменения языка - наличие в основе актов коммуникации отражения человеком окружающей его действительности.

Мышление и язык так же первичны, как и их носитель - человек. Мышление и язык не только отражают действительную жизнь, но сами являются частью ее и развиваются в тесном взаимодействии. Развитие и обогащение одного из них влечет за собой развитие и обогащение другого.

Опираясь на теорию контенсивной типологии Г.А. Климова и на представленный во второй и в третьей главе материал, мы видим путь становления КП в языке следующим образом:

Первые слова-предложения не различались в общекатегориальном плане и были пространственно-временными взаимоотношениями вещей, которые выражались простейшими классно-дейктическиит частицами.

В эпоху активного строя языка происходит грамматикализация бывших классно-дейктических частиц. Притяжательные связи выражаются простым расположением одного имени перед другим.

Версия выражает отчуждаемую (центробежную) и неотчуждаемую (центростремительную) принадлежность.

В позднеактивном состоянии языка происходит ослабление противопоставления субстантивов по классам активных и инактивных, что приводит к стиранию оппозиции форм органической и неорганической принадлежности в посессивной флексии имен существительных.

В связи с возникновением унифицированной категории притяжательности оказывается возможной передача отношений органической принадлежности показателем нецентробежной версии в словоформе глагола. 
Постепенная нейтрализация оппозиции двух форм принадлежности, сопровождается формированием унифицированной категории притяжательности; при этом иногда происходит обобщение формы органической принадлежности, иногда - неорганической. В языке устанавливается эргативный строй.

Сохранение или исчезновение двух форм принадлежности связано с былым существованием версионной диатезы активного глагола.

В рамках эргативного строя языка можно выделить посессивный строй как один из этапов развития языка.

При переходе от ЭК к номинативно-аккузативной расширяются возможности посессивных отношений. При схранении древнейших способов (простое соположение, версионность, личные местоимения) появляются дополнительные средства: притяжательный падеж, притяжательные местоимения, синтаксические конструкции и т.П.

Общая схема становления категории притяжательности на базе определенных элементов языка представляется следующим образом:

- Грамматикализация бывших классно-дейктических частиц начинается в эпоху развитого активного строя в языке.

- Древнейшим способом выражения притяжательных связей до возникновения падежной системы было простое расположение одного имени перед другим и произношение их одним речевым такTOM.

- С развитием падежной системы притяжательный (родительный) падеж начал вытеснять старый способ выражения притяжательности.

- Первоначально падежная оппозиция возникла в сфере местоимений, путем противопоставления форм основного и притяжательного падежей.

Эволюцию КП можно представить следующим образом (Схема № 4). 


\section{Схема 4}

\section{Становление категории притяжательности в языке}

\section{Классный строй}

Классно-дейктические частицы с диффузным значением

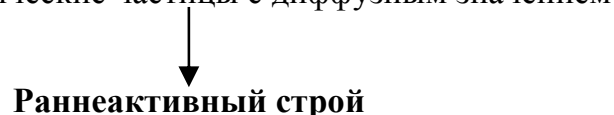

Разделение притяжательности на: органическую/неорганическую

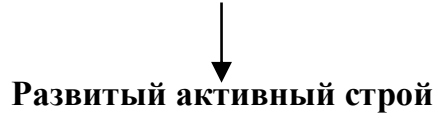

Активный / инактивный классы отражаются во всей структуре языка. Показатели органической и неорганической принадлежности переходят в активный / инактивный посессивы версии.

\section{Позднеактивный строй}

Выработка (формирование), притяжательных аффиксов, притяжательного падежа местоимений и имен, выделение притяжательных

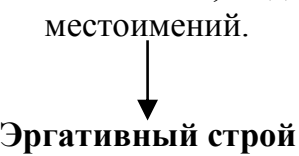

Эргатив сменяет активный падеж, вырабатывается посессивное выражение в имени и глаголе.

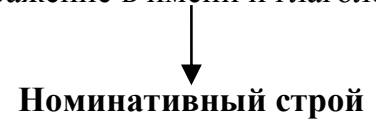

Наличие разных форм выражения посессивных отношений: личные и притяжательные местоимения; притяжательные, указательные аффиксы (предикативные суффиксы); родительный падеж имени, синтаксические конструкции (предложные, послеложные и др.). 


\section{ЗАКЛЮЧЕНИЕ}

Цель, поставленная нами в представленном исследовании, рассмотреть развитие и становление категории притяжательности в языках базируясь на материалах архаичных бесписьменных енисейских языков, вывести схему возникновеия и развития категории посессивности в языке в целом.

Под посессивностью в работе понимается одна из универсальных понятийных категорий языка, которая означает отношение между субъектом обладания (посессор, обладатель) и объектом обладания (possessum, обладаемое).

В синхронном и диахронном плане существуют две формы категории посессивности: отторжимой (неорганической) и неотторжимой (органической) принадлежности. Анализ материала языков различных структур показал, что во многих языках в большей или меньшей степени сохранились две формы принадлежности, как реликты «активного» прошлого.

Посессивные, экзистенциальные и пространственные отношения рассматриваются в работе как взаимосвязанные. Посессивные отношения диахронически являются разновидностью локативных.

С притяжательностью в енисейских языках тесно связана категория версии:

- В результативных формах категория версии у ряда глаголов, пересекаясь с категорией вида, трансформируется в посессивную конструкцию, заменяя современные глаголы обладания.

- Глагольные показатели группы $B$, которые тоже развились из аффиксов объектной версии в глагольных формах с бенефактивным значением, обнаруживают материальное единство с притяжательными приставками имени и формами родительного падежа личных местоимений.

- посессивные формы ряда глаголов могут заменяться обычными формами субъектной версии.

Диахронно-типологические параллели обнаруживаются в индоевропейских, картвельских и других языках.

Практически во всех упомянутых нами языках притяжательность может быть выражена формами личных и притяжательных местоимений.

Личные местоимения в форме исходного падежа выражают посессивные отношения в целом ряде языков различных семей, 
например, в финно-угорских языках. В большинстве же языков притяжательность выражена производными от личных местоимений: формой родительного падежа личных местоимений.

В процессе развития многих языков, имеющиеся личные местоимения уже в глубокой древности трансформировались в личнопритяжательные суффиксы, например, во всех западно-кавказских языках посессивность выражается префиксальными элементами, связанными генетически с личными или лично-классными местоимениями. Процесс формирования показателей-суффиксов притяжательности в отдельных языках заметен и сейчас.

Наиболее типичным для большинства языков, как мы установили, является выражение посессивных отношений с помощью притяжательных местоимений.

Во многих языках существует притяжательное склонение, где принадлежность предмета или лица кому или чему-нибудь выражается в самих существительных, обозначающих этот предмет (лицо), аффиксами личной принадлежности. К ним присоединяются в основном те же падежные аффиксы, что и в простом склонении, с незначительными в ряде случае фонетическими изменениями. Данный тип склонения присущ, например, тюркским, монгольским, тунгусо-маньчжурским языкам.

В притяжательном склонении финно-угорских и самодийских языков лично-притяжательные суффиксы почти тождественны, и все они восходят к финно-угорскому языку-основе.

В енисейских, в абхазском, адыгейском, кабардинском языках притяжательное склонение образуется посредством особых притяжательных префиксов, выражающих два типа принадлежности: имущественную и органическую.

Анализ материала различных языков показал, что притяжательные отношения выражаются и в структуре глагола (палеоазиатские, тюркские, тунгусо-маньчжурские, финно-угорские, кавказские и др. языки).

Лексически, т.е. специальными лексемами-глаголами обладания посессивность выражена в индоевропейских языках.

Синтаксический способ выражения категории притяжательности представлен с помощью особых конструкций: изафетных в тюркских языках, идафа в арабских, генетивные построения в афразийских языках, предложные конструкции в индоевропейских языках. 
Енисейские языки, которые являются для нас базовыми, поскольку они, будучи архаичными по своей структуре, сохранили следы предшествующих эпох в развитии таких языков, как индоевропейские.

Велика роль личных местоимений в выражении категории притяжательности в енисейских языках.

В формах склонения личных местоимений в единственном числе выступают две основы - основа формы основного падежа и основа формы притяжательного падежа, к которым присоединяются окончания остальных падежей. Основной падеж: 1-е л. $a d, 2$ е л. $u, 3$-л. $b u$ 'он, она'. Притяжательный (родительный) падеж соответственно: $a b, u k, b u d a$ 'его', budi 'её'.

В формах притяжательного падежа личных местоимений в кетском языке выделяются компоненты $\boldsymbol{b} \boldsymbol{b}-(<a b)-\boldsymbol{k}-, \boldsymbol{c} \boldsymbol{d}-$, выражающие лично-посессивное значение.

Притяжательный падеж местоимений третьего лица имеет формы buda 'его', budi ‘её', т.е. в этих формах выражается половое различие денотатов (для неодушевлённых предметов личного местоимения у кетов нет).

Типологические данные свидетельствуют о том, что личное местоимение 3-го лица восходит к указательному местоимению.

По нашим выводам, местоимение $b u$ представляет собой заимствование из западносибирских тюркских языков, где слово бу (bu) имеет значение указательного местоимения.

Опираясь на результаты исследований кетологов, мы пришли к выводу, что указательные местоимения являются наиболее древними из местоимений. Они служили средством выражения притяжательности. Это их значение вырабатывалось как переосмысление отношений пространственных: наиболее близко расположенное к говорящему воспринималось как 'мое', 'мне принадлежащее', более далеко расположенное - как 'не мое'.

Все суффиксы, из которых составляется отдельная словоформа, присоединяются к корню слова в типичном агглютинативном порядке. Как и у личных местоимений, все окончания местоименных падежей имеют в своем составе в качестве начального компонента лично-притяжательный суффикс: $\boldsymbol{b}$ - для первого лица, $\boldsymbol{k}$ - для второго лица, $\boldsymbol{d}$ - для третьего лица единственного числа и $\boldsymbol{n}$ - для всех лиц множественного числа. 
В енисейской системы склонения существительных в выражении притяжательных отношений доминирующую роль играет генитив, который мы вправе назвать притяжательным падежом, как выразитель всевозможных посессивных отношений.

Генитив принимает участие в образовании сложных слов - композитов. Члены этих слов-комплексов соединяются друг с другом с помощью форманта генитива, например: кет. des'tul' 'слеза' $<$ de $s^{\prime}$ 'глаз'+ $\boldsymbol{t}$ (формант генитива) $+u \cdot l^{\prime}$ 'вода'.

Эти сочетания слов напоминают чукотский инкорпорационный комплекс, например: кет. qaddsq-hol'ay-bul'ay-ass'en' 'те животные с очень короткими ногами' (tuna ass'en' qaddoq-hol'ay-bul'ay-ass'in 'эти животные с очень короткими ногами').

Всему комплексу может предшествовать посессивный личный префикс, образующий с определяемым именем существительным рамку, внутри которой размещается определяющая часть. Напри-

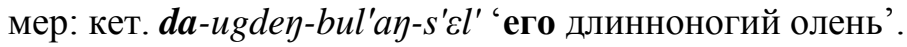

Форманты родительного падежа употребляются как префиксы,

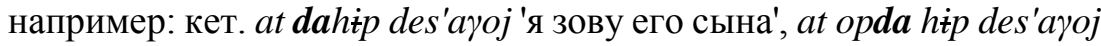
'я зову сына отца'.

Появление падежей в енисейских языках мы вслед за другими кетологами (М.А. Кастрен, В.Н. Топоров, Т.В. Цивьян, Е.А Крейнович, Г.К. Вернер, Г.Т. Поленова, Л.В. Буренко) связываем с основным падежом и возникновением оппозиции двух падежей: активного и инактивного. Формы двойных падежей использовались и используются до сих пор для выражения притяжательных отношений у имен активных. На основе родительного падежа впоследствии развилась целая группа падежей, имеющая в своем составе компонент (-b-, $-k-,-d-)$ с лично-посессивным значением.

В енисейских языках все элементы предложения отражаются в глагольной словоформе. Глаголы, оформленные показателями рядов $b a / b u$ и $b o / b u$, сохранили способность кетского языка выражать на уровне глагольной морфологии принадлежность действия лицу.

Вслед за Э. Вайдой, мы выделили в сложнейшей системе изменения кетского глагола посессивное (притяжательное) спряжение. Наиболее чётко оно прослеживается у глаголов, обозначающих шумовые эффекты и действия. В отличие от большинства глаголов, получающих субъектные показатели $\boldsymbol{B}$ или $\boldsymbol{D}$, такие глаголы упо- 
требляются с посессивными префиксами, как и имена существительные. При этом префиксы притяжательности могут заменяться полными притяжательными местоимениями.

Особое внимание мы уделили глаголам «быть» и «иметь» в кетском языке и рассмотрели их возможности выражать посессивные отношения.

В кетском языке, как и в языках активного строя, отсутствует специальный связочный глагол. Его заменяет серия личных и безличных предикативных суффиксов.

Полнозначный глагол представлен в кетском языке лексемами

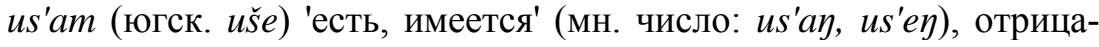
тельная форма $b ә n$ 's'aך и в прошедшем времени заимствованным из русского языка глаголом 'был', ср.: кет. obil'di ('я был')

В енисейских языках категория посессивности связана с различными (очень часто с пассивно-результативными) формами глагола, которые представляют собой в европейском понимании конструкции с глаголом 'быть' и в енисейских языках могут использоваться как habeo-конструкции (конструкции с глаголом 'uметь').

Verba habendi в енисейских языках можно образовать от всех имен существительных, которые могут обозначать объект обладания.

При анализе взаимосвязи эргативной и посессивной конструкций, мы пришли к выводу, что посессивная конструкция, является моделью посессивного предложения в эргативной типологии.

Енисейские языки имеют признаки эргативного строя.

Далее мы обобщили полученные данные и представили путь становления категории притяжательности.

Мы исходили из постулата, что каждый язык обладает универсальными свойствами. Универсальными являются понятия принадлежности (притяжательности, посессивности).

На древнем этапе развития языка притяжательные отношения выражались простым соположением имен. С развитием падежной системы притяжательный (родительный) падеж начал вытеснять старый способ выражения притяжательности. Падежная система в енисейских языках появилась на базе оппозиции двух падежей: основного и притяжательного. Первоначально падежная оппозиция возникла в сфере местоимений. 
Происхождение посессивной функции в языке мы связали с локативной. Пространство выступает как модель схемы притяжания - отчуждения. В енисейских языках отношение принадлежности также возникало как результат переосмысления отношений пространственных. Притяжательные аффиксы в енисейских языках развились из местоименных основ, выполняющих первоначальную функцию пространственных индикаторов.

Универсальным средством выражения категории притяжательности постепенно становятся притяжательные местоимения и притяжательные аффиксы, восходящие к формам личных местоимений.

В языке существуют два вида принадлежности: имущественная (отчуждаемая) и органическая (неотчуждаемая). Различие между ними заключается в отсутствии или присутствии соответственно посессивного маркера.

Одной из наиболее важных лексических импликаций активного строя языка является разделение имен существительных на активный и инактивный классы. Формы для выражения органической принадлежности имеют только существительные, соотносящиеся с именами активного класса.

Развитие категории притяжательности мы связали с таким атрибутом активного строя, как версия. Активный глагол различает формы центробежного («отчуждаемого») и нецентробежного («неотчуждаемого») действия, из которых развивается категория версии. Показатели версии, вошедшие в состав глагольной словоформы, а также в состав личных и притяжательных местоимений, трансформировались в показатели притяжательности.

Первичное енисейское сказуемое не было глаголом, оно выражало состояние субъекта с помощью предикативных показателей, а активное действие путем присоединения притяжательных приставок.

Глагол получил притяжательное оформление одновременно с именем. Это период притяжательного строя в языке в рамках эргативной типологии, когда не только притяжательные отношения между обладаемым и обладателем, но и другие типы грамматических отношений (ролевые - "актактные" валентности, локативные), могут выражаться посредством притяжательных форм.

Для языков эргативного строя характерно снятие противопоставления между двумя притяжательными формами отчуждаемой 
и неотчуждаемой принадлежности в именной морфологии. Выражение притяжательных отношений в глагольной словоформе сохраняется дольше.

В дальнейшем возникает унифицированная категория притяжательности (органической + неорганической).

В ходе дальнейшей эволюции в именной морфологии языков развивается падежная система. К средствам выражения категории притяжательности, различающей две формы принадлежности, добавляется категория падежа.

Эволюция категории притяжательности в языке представлена в Схеме 4. Таким образом, цель, поставленная в начале работы, представляется достигнутой.

Перспектива предложенной диссертации видится в исследовании других универсальных категорий языка в синхронно-диахронном аспекте. 


\section{БИБЛИОГРАФИЯ}

1. Ахманова, О.С. Словарь лингвистических терминов [Текст] / О.С. Ахманова. - М.: Советская энциклопедия. 1966. -605 с.

2. Баскаков, Н.А. Грамматика хакасского языка [Текст] / Н.А. Баскаков, - М.: Изд-во «Наука». 1975. - 417 с.

3. Бодуэн де Куртенэ И.А. Языковедение и язык: Исследования, замечания, программы лекций [Текст] / И.А. Бодуэн де Куртенэ. М.: Изд-во ЛКИ, 2010. - 216 с.

4. Буренко, Л.В. Эволюция категории падежа (на материале енисейских языков) [Текст] / Л.В. Буренко. Дисс. канд. филолог. наук. - Ростов-на-Дону, 2013. - 205 с.

5. Бюлер, K. Теория языка. Репрезентативная функция языка [Текст] / К. Бюлер. - М.: Прогресс, 2000. - 501 с.

6. Вайдa, Э. Актантные спряжения в кетском языке [Текст] / Э. Вайда. // Вопросы языкознания. 2000. - № 3. - С. 21-41.

7. Вайдa, Э. Что такое «ролевой язык» и почему кетский таковым не является [Текст] / Э. Вайда. Доклад на Чтениях памяти Е.А. Крейновича. Санкт- Петербург. 8 августа 2006 г.

8. Валл, М.Н., Функции и значения родительного падежа в кетском языке [Текст] / М.Н. Валл. // Языки и топонимика Сибири. Томск. 1972. - С. 33-34.

9. Валл, М.Н., Вернер Г.К. Об истоках падежной системы в енисейских языках [Текст] / М.Н. Валл, Г.К. Вернер. //Происхождение аборигенов Сибири и их языков: Материалы Всесоюзной конференции. 14-16 июня 1973 г. Томск, 1973. - С. 29-31.

10. Валл, М. Н., Канакин И. А. Категории имени в кетском языке [Текст] / М. Н. Валл, И. А. Канакин. - Новосибирск: Наука, 1985. $56 \mathrm{c}$.

11. Вернер, Г.К. Реликтовые признаки активного строя в кетском языке [Текст] / Г.К. Вернер. // Вопросы языкознания, 1974. № 1. - С. 34-45.

12. Вернер, Г. К. К вопросу о выделении частей речи в енисейских языках [Текст] / Г.К. Вернер // Исследования по грамматике и лексике енисейских языков. - Новосибирск: Наука. 1986. - С. 3- 11.

13. Вернер, Г.К. Сложные атрибутивные конструкции в енисейских языках [Текст] / Г.К. Вернер. // Вопросы языкознания. - 2000.№ 3- C. 42-49. 
14. Гамкрелидзе T.B. Иванов В.Вс. Индоевропейский язык и индоевропейцы. Т.1. [Текст] / Т.В.Гамкрелидзе, В.Вс. Иванов. - Тбилиси: Изд-во Тбилисского ун-та, 1984. - 435 с.

15. Гишев, H.T. О соотношении языка и мышления [Текст] / Вестник Адыгейского государственного университета. Серия 2: Филология и искусствоведение. Выпуск № 4 (107) / 2012. - С. 179184.

16. Головачева, A.B., Категория посессивности в плане содержания [Текст] //под ред. Вяч. Вс. Иванова. Категория посессивности в славянских и балканских языках . - М., 1989. - С. 44-111.

17. Грамматика Абхазского языка [Текст] / Под редакцией Ш.К. Аристава, Х.С. Бгажба, М.М. Циколия. Сухуми, 1968. -202 с. (ГАЯ).

18. Гримм, Я. Предисловие к «Немецкой грамматике» [Текст] / Я. Гримм, // Хрестоматия по истории языкознания XIX-XX веков. - М.: Гос. учебно-педагог. изд-во. 1956. -458 с.

19. Гумбольдm, В. фон. Язык и философия культуры. - М.: Прогресс, 1985. -449 с.

20. Дульзон, А.П. Кетский язык [Текст] / А.П. Дульзон. - Томск: Изд-во Томского университета, 1968. - 632 с.

21. Живова-Поленова, Г.Т. Местоимения в кетском языке (сравнительно-типологическое исследование местоимений кетского языка в сопоставлении с местоимениями других языков). - Автореф. канд. дис. [Текст] / Г. Т. Живова-Поленова. - Л., 1978. - 21с.

22. Иванов Вяч.Всев. Типология и сравнительно-историческое языкознание [Текст] / Вяч.Вс. Иванов // ВЯ. 1958. -№ 5. - С. 34-42.

23. Иванов, Вяч.Всев. Праязыки как объект описания в издании «Языки мира» [Текст] / Вяч.Вс. Иванов. // Теоретические основы классификации языков мира. Наука, Москва 1980. Prajazyki kak objekty opisanija v izdanii "Jazyki mira". - Teoreticeskie osnovy klassifikacii jazykov mira. Nauka, Moskva 1980: 181-207.

24. Иванов, Вяч. Всев. Синхронная и диахроническая типология посессивности [Текст] / В. Всев. Иванов // Категория посессивности в славянских и балканских языках. - М.: Наука, 1989. - С. 5-43.

25. Камова, И.М. Фрагмент грамматики употребления именных посессивных конструкций [Текст] / И.М. Камова, // Морфология имени в Сибирских языках. Сборник научных трудов. - Новосибирск, ГПНТБ СО АН СССР, 1981. - С . 57-62. 
26. Карташова, E.A. Внешние и внутренние причины изменения и развития языка [Текст] / Е.А. Карташова // Актуальные вопросы теории и практики филологических исследований: материалы международной научно-практической конференции 25-26 марта 2011 года. - Пенза - Москва - Решт: Научно-издательский центр «Социосфера», 2011. - С 17-20.

27. Кассирер, Э. Философия символических форм. Т.1. Язык [Текст] / Э. Кассирер. - М.: СПб.: Университетская книга, 2002. $272 \mathrm{c}$.

28. Категория посессивности в славянских и балканских языках [Текст] / под ред. Вяч. Вс. Иванова. - М., 1989. - 260 с.

29. Категория посессивности в славянских и балканских языках. Тезисы совещания [Текст] / под ред. Вяч. Вс. Иванова, Т.Н. Молошной, Т.Н. Николаевой. - М.: Наука, 1983. - 124 с.

30. Кацнельсон, С.Д. Общее и типологическое языкознание [Текст] / С.Д. Кацнельсон. - Л.: Наука, 1986. - 298 с.

31. Кибрик, А.Е. Очерки по общим и прикладным вопросам языкознания (универсальное, тоновое и специфическое в языке) [Текст] / А.Е. Кибрик. - М.: КомКнига, 2005. - 337 с.

32. Кибрик A.E. Материалы к типологии эргативности [Текст] / А.Е. Кибрик. // Предварительные публикации ИРЯ АН СССР. Вып. 126-130, 140-141. М., 1979-1981.

33. Климов Г.А К характеристике языков активного строя [Текст] / Г.А. Климов // ВЯ, 1972. -№ 4. - С. 3-13.

34. Климов, Г. А. Очерк общей теории эргативности [Текст] / Г.А. Климов. - М.: Изд-во Наука, 1973. - 264 с.

35. Климов, Г.А. Типология языков активного строя [Текст] / Г.А. Климов. - М.: Изд-во «Наука».1977. - 317 с.

36. Косериу, Э. Синхрония, диахрония и история. Проблема языкового изменения // Новое в лингвистике. - Вып. 3. - М.: Издво иностр-ной лит-ры, 1963. - С. 143-309.

37. Краснощеков, E.B. Посессивность в системе глагола [Текст]/ Е.В. Краснощеков. // Известия Южного федерального университета. Филологические науки. 2008а №3. - Ростов-наДону. С. 88-94. 
38. Краснощеков, Е.В. Притяжательность и личные местоимения в палеоазиатских языках [Текст] / Е.В. Краснощеков. // Московский социально-гуманитарный институт. Социально-экономические аспекты образования и научного познания в XXI веке. Материалы научно-практической конференции. Таганрог 2008c. C. 92-97.

39. Краснощеков, E.B. Местоимения как средство выражения притяжательности в енисейских языках [Текст] / Е.В. Краснощеков. // Язык Дискурс текст. Материалы IV международной научной конференции. ТТИ ЮФУ. - Ростов-на-Дону. 2012. - С.119-123.

40. Краснощеков, E.B. Местоимения как средство выражения притяжательности в енисейских языках [Текст] / Е.В. Краснощеков // Язык. Дискурс. Текст. Материалы IV международной научной конференции. ТТИ ЮФУ, - Ростов-на-Дону, 2012. - С. 119-123.

41. Краснощеков, E.В. Выражение притяжательных отношений в финно-угорских языках с помощью порядка слов [Текст] / Е.В. Краснощеков // Сборник статей международной научно-практической конференции. ТТИ ЮФУ - Таганрог, 2012. - С. 140-145.

42. Краснощеков, E.В. Средства выражения притяжательности в финно-угорских языках [Текст] / Е.В. Краснощеков // Известия Волгоградского педагогического гос-го унив-та. Серия «Филологические науки». - № 1. Изд-во «Перемена» ВГСПУ, - Волгоград. 2013. - С. $40-43$.

43. Краснощеков, Е.В. Посессивная конструкция в енисейских языках [Текст] / Е.В. Краснощеков // Известия Южного федерального университета. Серия «Филологические науки» № 1. Ростовна-Дону. Изд-во ЮФУ. 2013. - С.136-143.

44. Краснощеков, E.В. Эргативная конструкция в енисейских языках [Текст] / Е.В. Краснощеков. // Вестник Челябинского государственного университета. Серия «Филология. Искусствоведение», 2013. -С. 25-29.

45. Краснощеков, E.B. Выражения категории принадлежности в тюркских языках с помощью изафетных конструкций [Текст] / Е.В. Краснощеков // «European Social Science Journal» Европейский журнал социальных наук. - № 10. т. 2 (49), - Москва, 2014. - С. 230 238.

46. Краснощеков, E.B. Категория притяжательности и ее выражение в енисейских языках [Текст] / Е.В. Краснощеков. - Таганрог, Изд-во ЮФУ, 2016. - 218 с. 
47. Крейнович, E.A. Об инкорпорировании в нивхском языке [Текст] / Е.А. Крейнович // ВЯ, 1958. - № 6. - С. 21-33.

48. Крейнович, Е.А. Юкагирский язык [Текст] / Е.А. Крейнович. - М. - Л.: Академия наук СССР, 1958. - 288 с.

49. Крейнович, Е.А. Глагол кетского языка [Текст] / Е.А. Крейнович. - Л.: Наука, $1968 \mathrm{a}-283$ с.

50. Крейнович E.A. Способы действия в глаголе кетского языка [Текст] / Е.А. Крейнович. // Кетский сборник. Лингвистика. М.: «Наука». 1968. - С.75-138.

51. Кузьменко, Ю.К. Лингвистическая концепция Расмуса Раска [Текст] / Ю.К. Кузьменко, // Понимание историзма и развития в языкознании первой половины XIX века. - Ленинград: Наука, 1984. - С.16-53.

52. Кумахов М.А. Сравнительно-историческая грамматика адыгских (черкесских) языков [Текст] / М.А. Кумахов. - М.: Наука, 1989. - 383 c.

53. Лафарг, П. Язык и революция. Французский язык до и после революции. Очерки происхождения современной буржуазии [Текст] / П. Лафарг // Литературно-критические статьи. - М.: Художеств, лит-ра, 1936. 100 с.

54. Лосев, А.Ф. Знак. Символ. Миф. [Текст] / А.Ф. Лосев // Труды по языкознанию. - Издательство Московского Университета. 1982. - 343 с.

55. Майтинская K.E., Местоимения в языках разных систем [Текст] / К.Е. Майтинская. - М.: Наука.2009. -307 с.

56. Майтинская, K.E. Неопределенный падеж и абсолютная форма в венгерском языке [Текст] / К.Е. Майтинская. - М.: Уч. зап. Военного ин-та иностранных языков. № 6. 1948. - С. 67-77.

57. Максунова, 3.В. Выражение отрицания в кетском языке [Текст] / 3.В. Максунова. // Вопросы теории и методики преподавания иностранных языков. Ч. І. - Таганрог: ТГПИ, 2009. - С. 156-160.

58. Мартине, A. Структурные вариации в языке [Текст] / А. Мартине // Новое в лингвистике. - Вып. 4. - М., 1965 - С. 450-465.

59. Мейе, $A$. Введение в сравнительное изучение индоевропейских языков [Текст] / А. Мейе. - М.: УРСС. 2002. - 510 с.

60. Мейе, $A$. Сравнительный метод в историческом языкознании [Текст] / А. Мейе. - М.: УРСС. 2004. - 103 с. 
61. Мельников, Г.П. Системная типология языков: синтез морфологической классификации языков со стадиальной: Курс лекций [Текст] / Г.П. Мельников. - М.: Изд-во РУДН, 2000. - 73 с.

62. Мельчук, И.А., Еще раз к вопросу об эргативной конструкции [Текст] / И.А. Мельчук // Вопросы языкознания. - 1991. - № 4. - C. $46-88$.

63. Мещанинов, И.И. Палеоазиатские языки [Текст] / И.И. Мещанинов. // ИАН ОЛЯ, -1948, т.VII, выпуск 6. - С. 509.

64. Морган Льюис Г. Древнее общество или исследование линий человеческого прогресса от дикости через варварство к цивилизации $[$ Текст] / Г. Морган Льюис. - Ленинград: Изд-во Института народов Севера ЦИК СССР. 1935 - 350 с.

65. Николаева, T.M. «Скрытая память» языка: постановка проблемы [Текст] / Т.М.Николаева // Вопросы языкознания. 2002. № 4. - C. 25-41.

66. Николаева, Т.M. Непарадигматическая лингвистика (История блуждающих частиц) [Текст] / Т.М.Николаева. - М.: Наука, 2008. $-376 \mathrm{c}$.

67. Осипова, О.А. Существовало ли посессивное склонение в древних индоевропейских языках [Текст] / О.А. Осипова // Индоевропейские и уральские языки. Избранные труды. Томск, 2010. $311 \mathrm{c}$.

68. Пауль, Г. Принципы истории языка [Текст] / Г. Пауль, - М.: Изд-во иностр. лит-ры, 1960. - 501 с.

69. Поленова Г.Т. Сопоставительнй анализ кетских л/м 3-го лица [Текст] / Г. Т. Поленова // В поисках истоков языка. - Таганрог: Изд-во ФГБОУ ВПО, 2011. - С. 108-113. (108-109)

70. Поленова, $Г$. Т. Происхождение грамматических категорий глагола (на материале енисейских языков) [Текст] / Г. Т. Поленова. - Таганрог : Изд-во Таганрогского государственного педагогического института, 2002. $-202 \mathrm{c}$.

71. Поленова, Г. Т. Следы классного строя в енисейских языках [Текст] / Г.Т. Поленова // Филологический вестник Ростовского государственного университета. - 2006. - № 2. - С. 27-34.

72. Поленова, Г.Т. Вопросы генезиса некоторых формантов кетского глагола [Текст] / Г.Т. Поленова // Вопросы языкознания. 1987. - № 4. - C. 74-82. 
73. Поленова, Г.Т. Грамматические категории кетских личных местоимений [Текст] / Г.Т. Поленова // В поисках истоков языка. Изд-во ФГБОУ ВПО. - Таганрог 2011. - С. 94-102.

74. Поленова, Г.Т. К структуре кетского глагола (вторичные предикаты). [Текст] / Г.Т. Поленова // В поисках истоков языка. Изд-во ФГБОУ ВПО. Таганрог. 2011. - С. 137-139.

75. Поленова, Г.Т. Кетские глаголы посессивного спряжения [Текст] / Г.Т. Поленова // Сравнительно-историческое и типологическое изучение языков и культур. - Томск. 2008. - С.134-139.

76. Поленова, Г.Т. Кетские грамматические показатели местоименного происхождения [Текст] / Г.Т. Поленова // В поисках истоков языка. Изд-во ФГБОУ ВПО. - Таганрог 2011. - С. 104-105.

77. Поленова, Г.Т. Категория версии - свидетельство былого состояния языка [Текст] / Г.Т. Поленова // В поисках истоков языка. Изд-во ФГБОУ ВПО. - Таганрог 2011. - С. 49-54.

78. Поленова, Г.Т. Личные глагольные показатели в енисейских и кавказских языках [Текст] / Г. Т. Поленова // В поисках истоков языка. - Таганрог. 2011. - С. 139-150.

79. Поленова, Г.Т. О происхождении кетских личных местоимений [Текст] / Г.Т. Поленова // В поисках истоков языка. Изд-во ФГБОУ ВПО. - Таганрог 2011 . - С. 102-103.

80. Поленова, Г.Т. Версионные реликты в кетском глаголе [Текст] / Г.Т. Поленова // В поисках истоков языка. Изд-во ФГБОУ ВПО. - Таганрог 2011. - С. 179-184.

81. Потебня, А.А. Слово и предложение. Введение в теорию [Текст] / А.А. Потебня, - М .: URSS. 2014. - 124 с.

82. Потебня, А.А. Из записок по русской грамматике. Члены предложения и части речи. // Отечественная лингвистика: от А.А. Потебни до В.В. Виноградова: Хрестоматия / Сост. Е.А. Красина. М.: Изд-во РУДН, 2006. - 254 с.

83. Серебреников, Б.А., Гаджиева Н.3. Сравнительно-историческая грамматика тюркских языков [Текст] / Б.А. Серебреников, Н.3. Гаджиева. - Баку: Изд-во «Маариф», 1979. - 302 с.

84. Серебренников, Б.А. Роль человеческого фактора в языке. Язык и картина мира [Текст] / Б.А. Серебренников, - М.: Наука. $1988.216 \mathrm{c}$.

85. Серебреников, Б.А., Гаджиева Н.3. Сравнительно-историческая грамматика тюркских языков [Текст] / Б.А. Серебреников, Н.3. Гаджиева. - М.: Наука, 1986. - 285 с. 
86. Серебренников, Б.А. Об относительной самостоятельности развития системы языка [Текст] / Б.А. Серебренников. - М.: Наука. 1968. - $127 \mathrm{c}$.

87. Соссюр Ф. де. Курс общей лингвистики [Текст] / Ф. де Соссюр. - М.: Ком. Книга, 2006. - 270 с.

88. Степанов, Ю.С. Имена. Предикаты. Предложения. (Семиологическая грамматика) [Текст] / Ю.С. Степанов. - М.: Наука, 1981. - $361 \mathrm{c}$.

89. Топоров, B.H. К генезису категории притяжательности [Текст] / В.Н. Топоров // Категория притяжательности в славянских и балканских языках. М.: Наука. 1983 - С. 99-107.

90. Уленбек, X.K. Agens и Patiens в падежной системе индоевропейских языков [Текст] / Х.К. Уленбек // Эргативная конструкция предложения. - М., 1950б. - С. 101-103.

91. Уленбек, Х.К. К учению о падежах [Текст] / Х.К. Уленбек // Эргативная конструкция предложения. - М., 1950а. - С. 97-100.

92. Уленбек, Х.К. Идентифицирующий характер посессивной флексии в языках Северной Америки [Текст] / Х.К. Уленбек // Эргативная конструкция предложения. - М., 1950с. - С.189.

93. Услар, П.К. О распространении грамотности между горцами [Текст] / Л.К. Услар. // Сборник сведений о кавказских горцах. Вып. III. Раздел IV. Горская летопись. - Тифлис, 1870. - С. 1-30.

94. Успенский Б.А. О системе кетского глагола [Текст] / Б.А. Успенский. // Кетский сборник. Лингвистика. Главная редакция восточной литературы. - М., 1968. - С.196-228.

95. Ушинский, К.Д. Педагогические сочинения [Текст] / К.Д. Ушинский Т. 2. - М.: Педагогика, 1988. - 543 с.

96. Фортунатов, Ф.Ф. Избранные труды [Текст] / Ф.Ф. Фортунатов, - М.: Гос. уч.-пед. изд-во Министерства просвещения РСФСР, 1956. T.I. - 452 c.

97. Фосслер, К. Эстетический идеализм. Избранные статьи по языкознанию [Текст] / К. Фосслер - М : Изд-во ЛКИ, 2007. - 138 с.

98. Цыдендамбаев, Ц.Б. Грамматические категории бурятского языка в историко-сравнительном освещении [Текст] / Ц.Б. Цыдендамбаев. - Москва, 1979. - 145 с.

99. Шабаев, В.Г. «Функциональный анализ системы субъектнообъектных показателей кетского глагола». В.Г. Шабаев - АКД. Ленинград, 1984. 
100. Шабаев, В.Г. Проявление черт эргативности в использовании личных показателей кетского глагола [Текст] / В.Г.Шабаев // Палеоазиатские языки. - Ленинград, 1984. - С. 253.

101. Шлейхер, А. Немецкий язык [Текст] /В.А. Звегинцев // История языкознания XIX и XX веков в очерках и извлечениях Ч. I. M., 1960. - 405 c.

102. Шухардm, Гуго. Избранные статьи по языкознанию [Текст] / Г.Шухардт. - М: Едиториал УРСС, 2003. - 292 с.

103. Щедровицкий, Г.П. Методологические замечания к проблеме происхождения языка [Текст] / Щедровицкий // Филологические науки. - 1963. - № 2. - C. 7-8 (http://www.moglobi.ru/stati/gp-shedrovickij-metodologicheskie-zamechaniya-k-problemeproi/main.html).

104. Яковлев Н.Ф., Ашхамаф Д.А., Грамматика адыгейского литературного языка, [Текст] / Н.Ф. Яковлев, Д.А. Ашхамаф, - М.; Ленинград: 1941, - 462 с.

105. Яковлев, Г.Ю. Принципы системного моделирования языковых процессов [Текст] / Г.Ю. Яковлев. - М., 2008. - 169 с.

106. Boas, F. Handbook of American Indian Languages [Text] / F. Boas, - Washington, p. I, 1911, p. II, 1922. - 2679 p.

107. Bouda, Karl. Die Sprache der Jenissejei. Genealogische und morphologische Untersuchungen. - „Anthropos“, vol. 52, 1957, № 1-2.

108. Brugmann, Karl. Die Demonstrativpronomina der indogermanischen Sprachen. -Abhandlungen der philologisch-historischen Klasse der königlich-sächsischen Gesellschaft der Wissenschaften. Bd. XXII, VI. Leipzig, 1904.

109. Bühler, K. Sprachtheorie. Die Darstellungsfunktion der Sprache [Text] / K.Bühler. Jena, 1934. - 504 S.

110. Castrén, M.A. Versuch einer Jenissei-Ostjakischen und kottischen Sprachlehre nebst Wörterverzeichnissen aus den genannten Sprachen [Text] / M.A. Castrén. - St. Petersburg. Buchdrückerei der Keiserlichen Akademie der Wissenschaften, 1858. - 125 S. 154 c.

111. Georg, Stefan Türkisch/mongolisch tengri „Himmel, Gott’und seine Herkunft“" [Text] // Studia Etimologyka, vol. 6. - Kraków. 2001. P. 83-100.

112. Hirt, H. Geschichte der Deutschen Sprache [Text] / H. Hirt. München, 1925. - 299 S.

113. Seiler, $H$. Possession as an Operational Dimension of Language [Text] / H. Seiler. - Tubingen, 1983. - 156 p. 
114. Story G.L., Naish C.M. Tlingit verb dictionary [Text] / G.L. Story, C.M. Naish. - Fairbanks, 1973. - 392 p.

115. Werner $H$. Das Klassensystem in den Jenissej-Sprachen / H. Werner. - Veröffentlichungen der Societas Uralo-Altaica 40. Harrassowitz Verlag, Wiesbaden 1994. - $192 \mathrm{~S}$.

116. Werner H. Abriß der kottischen Grammatik [Text] / H. Werner. - Tunguso-Sibirica 4. Harrassowitz Verlag, Wiesbaden 1997a. $163 \mathrm{~S}$.

117. Werner H. Die ketische Sprache [Text] / H. Werner. - TungusoSibirica B. Harrassowitz Verlag, Wiesbaden, 1997b. - 405 S.

118. Werner H. Das Jugische (Sym-Ketische). Veröffentlichungen der Societas Uralo-Altaica. Band 50. Harrassowitz Verlag -Wiesbaden. 1997c. 312 S.

119. Werner H. Vergleichendes Wörterbuch der Jenissei-Sprachen, Bd. 1-3, Harrassowitz Verlag, Wiesbaden. 2002.

120. Werner H. Die Diathese in den Jenissej-Sprachen aus typologischer Sicht. = Veröffentlichungen der Societas Uralo-Altaica 64. Harrassowitz Verlag, Wiesbaden. 2004a. -158 S.

121. Young R.W., Morgan W. The Navaho Language. Salt Lake City, Utah. 1972.499 p. 


\section{СПИСОк яЗЫКОВ}

\section{АФРАЗИЙСКИЕ ЯЗЫКИ}

с.-х. - семито-хамитские

араб. - арабский язык

\section{ИБЕРИЙСКО-КАВКАЗСКИЕ ЯЗЫКИ}

\section{Картвельские языки}

Aбхазо-адыгская групnа (зап.-кавк. - западнокавказские языки)

абх. - абхазский

абаз. - абазинский

убых. - убыхский

адыг. - адыгейский

абадз. - абадзехский диалект (адыг. язык)

шапс. - шапсугский диалект (адыг. язык)

каб.-черк. - кабардино-черкесский

каб. - кабардинский язык

бесл. - бесланеевский диалект

Нахско-дагестанская группа

аваро-андийские языки:

авр. - аварский

лезгинские языки

лезг. - лезгинский язык

\section{ИНДЕЙСКИЕ ЯЗЫКИ}

\section{Североамериканские языки}

атаб. - атабаские языки

квак. - квакиутль

на-д. - на-дене

муск. - мускоги

дак. - сиу (дакота)

тлинг. - тлингит

хид. хидатса

чер. - чероки

эяк - эяк 


\section{ИНДОЕВРОПЕЙСКИЕ ЯЗЫКИ}

\section{Германские языки}

англ. - английский язык

нем. - немецкий язык

Славянские языки

Романские языки

франц. французский язык (романские языки)

\section{МЕЛАНЕЗИЙСКИЕ ЯЗЫКИ}

мот. - мота язык

суау язык

фид. - фиджи

\section{МОНГОЛЬСКИЕ ЯЗЫКИ}

бур. - бурятский

калм. - калмыцкий

монг. - монгольский

\section{ПАЛЕОАЗИАТСКИЕ}

аль. - алеутский язык

буруш. - бурушаски (язык)

нивх. - нивхский язык

чук. - чукотский язык

эск. - эскимосский

юкаг. - юкагирский

Енисейские языки

пр.-ен. - праенисейский

кет. - кетский (имбатский говор) язык

кет.-югск. - кетско-югский язык

котт. - коттский язык

\section{ТУНГУСО-МАНЬЧЖУРСКИЕ ЯЗЫКИ}

нан. - нанайский

удэг. - удэгейский

эвен. - эвенский

\section{ТЮРКСКИЕ ЯЗЫКИ}

азерб. - азербайджанский

алт. - алтайский язык

башк. - башкирский

караим. - караимский 
тоф. - тофаларский

тур. - турецкий

тюрк. - тюркский

хак. - хакасский

якут. - якутский

\section{ФИННО-УГОРСКИЕ ЯЗЫКИ}

венг. - венгерский

манс. - мансийский

мар. - марийский

Мордовские языки

мокш. - мокшанский

эрз. - эрзянский

Прибалтийско-финские языки

фин. - финский

саам. - саамский язык

удм. - удмуртский

Самодийские языки

нен. - ненецкий

сельк. - селькупский язык

Изолированные языки

баск. - баскский язык

не.-ин.ев. - неиндоевропейский язык

австралийские языки

балканские языки

хурритско-урартские языки

шумерские 
Для заметок 
Для заметок 
Для заметок 
Научное издание

Краснощеков Евгений Владиславович

ВОЗНИКНОВЕНИЕ И РАЗВИТИЕ КАТЕГОРИИ ПОСЕССИВНОСТИ

\author{
Монография \\ Чебоксары, 2019 г.
}

Редактор Е.В. Краснощеков

Компьютерная верстка и правка Т.В. Яковлева

Дизайн обложки Н.B. Фирсова

Подписано в печать 31.07.2019 г.

Дата выхода издания в свет 01.08.2019 г.

Формат $60 \times 84 / 16$. Бумага офсетная. Печать офсетная.

Гарнитура Times. Усл. печ. л. 4,8825. Заказ К-513. Тираж 500 экз.

Издательский дом «Среда»

428005, Чебоксары, Гражданская, 75, оф.12

+7 (8352) 655-731

info@phsreda.com

www.phsreda.com

Отпечатано в Студии печати «Максимум»

428005, Чебоксары, Гражданская, 75

+7 (8352) 655-047

info@maksimum21.ru

www.maksimum21.ru 